\title{
Pharmacological treatment options for mast cell activation disease
}

\author{
Gerhard J. Molderings ${ }^{1}$ • Britta Haenisch ${ }^{2}$ - Stefan Brettner ${ }^{3}$ • Jürgen Homann ${ }^{4}$ • \\ Markus Menzen $^{4}$ - Franz Ludwig Dumoulin ${ }^{4}$. Jens Panse ${ }^{5}$ • Joseph Butterfield ${ }^{6}$. \\ Lawrence B. Afrin ${ }^{7}$
}

Received: 24 March 2016/Accepted: 11 April 2016/Published online: 30 April 2016

(C) The Author(s) 2016. This article is published with open access at Springerlink.com

\begin{abstract}
Mast cell activation disease (MCAD) is a term referring to a heterogeneous group of disorders characterized by aberrant release of variable subsets of mast cell (MC) mediators together with accumulation of either morphologically altered and immunohistochemically identifiable mutated MCs due to $\mathrm{MC}$ proliferation (systemic mastocytosis [SM] and MC leukemia $[\mathrm{MCL}]$ ) or morphologically ordinary MCs due to decreased apoptosis (MC activation syndrome [MCAS] and well-differentiated SM). Clinical signs and symptoms in MCAD vary depending on disease subtype and result from excessive mediator release by MCs and, in aggressive forms, from organ failure related to MC infiltration. In most cases, treatment of MCAD is directed primarily at controlling the symptoms associated with MC mediator release. In advanced forms, such as aggressive SM and MCL, agents targeting MC
\end{abstract}

Gerhard J. Molderings

molderings@uni-bonn.de

1 Institute of Human Genetics, University Hospital of Bonn, Sigmund-Freud-Strasse 25, 53127 Bonn, Germany

2 German Center for Neurodegenerative Diseases (DZNE), Bonn, Germany

3 Department of Oncology, Hematology and Palliative Care, Kreiskrankenhaus Waldbröl, Waldbröl, Germany

4 Allgemeine Innere Medizin, Gastroenterologie und Diabetologie, Gemeinschaftskrankenhaus, Bonn, Germany

5 Department of Hematology, Oncology and Stem Cell Transplantation, Medical Faculty, RWTH Aachen University, Aachen, Germany

6 Program for the Study of Mast Cell and Eosinophil Disorders, Mayo Clinic, Rochester, MN 55905, USA

7 Division of Hematology, Oncology, and Transplantation, University of Minnesota, Minneapolis, MN 55455, USA proliferation such as kinase inhibitors may be provided. Targeted therapies aimed at blocking mutant protein variants and/or downstream signaling pathways are currently being developed. Other targets, such as specific surface antigens expressed on neoplastic MCs, might be considered for the development of future therapies. Since clinicians are often underprepared to evaluate, diagnose, and effectively treat this clinically heterogeneous disease, we seek to familiarize clinicians with MCAD and review current and future treatment approaches.

Keywords Mast cell $\cdot$ Mast cell activation disease $\cdot$ Systemic mastocytosis - Systemic mast cell activation syndrome ·

Therapy

\section{Introduction}

Mast cells (MCs, Fig. 1) are immune cells of hematopoietic origin found in all human tissues, especially at the environmental interfaces. They act as both effector and regulatory cells and play a central role in adaptive and innate immunity (Anand et al. 2012; Gri et al. 2012). Their important role in immunological as well as non-immunological processes is reflected by the large number of mediators $(>200)$ including pre-stored ones such as histamine and tryptase as well as numerous mediators synthesized de novo in response to allergic or non-immune triggers such as chemokines and cytokines, by which MCs may influence other cells (Lundequist and Pejler 2011; Ibelgaufts 2016). Their evolved arrays of sensory and response mechanisms engender diverse havoc when MC dysfunction emerges.

The umbrella term mast cell activation disease (MCAD; Akin et al. 2010) comprises the full spectrum of primary systemic MC disease, i.e., systemic mastocytosis (SM) which is 


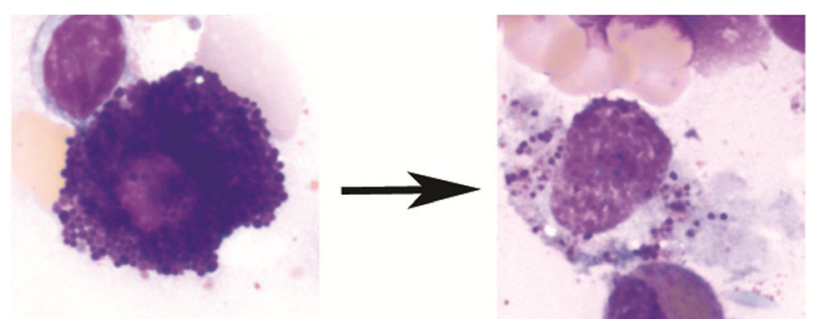

Resting mast cell

Activated mast cell

Fig. 1 May-Grünwald/Giemsa stain of a resting human mast cell and a mast cell following activation-induced degranulation. Note the loss of granule staining. Mast cells obtained from the human bone marrow, magnification $1000 \times$

further divided into several subtypes (Valent et al. 2007; Tables 1 and 2), primary MC activation syndrome (MCAS; Table 3; Molderings et al. 2011a; Hamilton et al. 2011; Valent et al. 2012), and MC leukemia (MCL). Pathogenetically, MCAD denotes a group of polygenic MC disorders (Molderings 2015, 2016) characterized by aberrant release of variable subsets of MC mediators and also an accumulation of either morphologically altered and immunohistochemically identifiable mutated MCs due to MC proliferation (SM and MCL) or morphologically ordinary MCs due to decreased apoptosis (MCAS; Kohno et al. 2005; Aichberger et al. 2009; Karlberg et al. 2010a). According to recent molecular genetic findings (Molderings 2015, 2016; Haenisch et al. 2014; Lasho et al. 2016), the subclasses and clinical subtypes of MCAD do not represent distinct disease entities but should be more accurately regarded as variable presentations of a common generic state of $\mathrm{MC}$ dysfunction (Molderings et al. 2007, 2010; Hermine et al. 2008; Akin et al. 2010). Due to both the widespread distribution of MCs and the great heterogeneity of aberrant mediator expression patterns, symptoms can occur in virtually all organs and tissues; hence, the clinical presentation of MCAD is very diverse, sometimes to the even-

Table 1 WHO 2008 diagnostic criteria for systemic mastocytosis (Valent et al. 2001)

\section{Major criterion:}

1. Multifocal, dense aggregates of MCs ( 15 or more) in sections of the bone marrow or other extracutaneous tissues and confirmed by tryptase immunohistochemistry or other special stains

Minor criteria:

1. Atypical or spindled appearance of at least $25 \%$ of the MCs in the diagnostic biopsy

2. Expression of CD2 and/or CD25 by MCs in the marrow, blood, or extracutaneous organs

3. KIT codon 816 mutation in the marrow, blood, or extracutaneous organs

4. Persistent elevation of serum total tryptase $>20 \mathrm{ng} / \mathrm{ml}$

Diagnosis of SM made by either (1) the major criterion plus any one of the minor criteria or (2) any three minor criteria further-confounding point of presenting opposite abnormalities in different patients (or even in the same patient at different times, or in different sites in the same patient at the same time). While the prevalence of SM in Europeans ranges between 0.3 and 13 per 100,000 (Haenisch et al. 2012; Cohen et al. 2014; van Doormaal et al. 2013), the prevalence of MCAS may be as high as $17 \%$ (in Germany; Molderings et al. 2013a, b).

This review focuses on the current state of drug therapy in SM and MCAS and describes perspectives of promising new approaches for drug treatment. Compounds in various stages of preclinical and clinical development are summarized in tables. We first describe drugs that are currently available and either are used on a regular basis in MCAD therapy or have been used successfully in single MCAD cases. In this context, it should be noted that there is no official guideline for treatment of MCAD.

\section{Treatment options}

Due to its genetic roots, MCAD generally is regarded as incurable. Recent mutational studies revealed that each patient has an individual pattern of genetic and epigenetic alterations which may affect the intracellular signal transduction pathways and receptive sites involved in sensory perception. As a consequence, mediator formation and release as well as inhibition of apoptosis and/or increase in proliferation are determined by individual genetic and epigenetic conditions (Fig. 2) and represent potential targets for therapy. Hence, there is need of highly personalized therapy for the disease. Unfortunately (with regard to easy detection), most genetic alterations (with a few exceptions such as certain mutations

Table 2 Classification of systemic mastocytosis (modified form Valent et al. 2007)

\begin{tabular}{|c|c|}
\hline $\begin{array}{l}\text { Categories of systemic } \\
\text { mastocytosis (SM) }\end{array}$ & Subtypes \\
\hline Indolent systemic mastocytosis & $\begin{array}{l}\text { - Smoldering systemic mastocytosis } \\
\text { - Isolated bone marrow } \\
\text { mastocytosis } \\
\text { - Well-differentiated systemic } \\
\text { mastocytosis }\end{array}$ \\
\hline $\begin{array}{l}\text { Aggressive systemic mastocytosis } \\
\text { (ASM) }\end{array}$ & - ASM in transformation \\
\hline $\begin{array}{l}\text { Systemic mastocytosis with an } \\
\text { associated clonal hematological } \\
\text { non-mast cell lineage disease }\end{array}$ & $\begin{array}{l}\text { - SM-acute myeloid leukemia } \\
\text { - SM-myelodysplastic syndrome } \\
\text { - SM-myeloproliferative neoplasm } \\
\text { - SM-chronic myelomonocytic } \\
\text { leukemia } \\
\text { - SM-chronic eosinophilic leukemia } \\
\text { - SM-non-Hodgkin lymphoma } \\
\text { - SM-multiple myeloma }\end{array}$ \\
\hline
\end{tabular}


Table 3 Current provisional criteria to define mast cell activation syndrome (MCAS; modified from Afrin and Molderings 2014)

Major criterion

Constellation of clinical complaints attributable to pathologically increased mast cell activity (mast cell mediator release syndrome)

Minor criteria

1. Focal or disseminated increased number of mast cells in marrow and/or extracutaneous organ(s) (e.g., gastrointestinal tract biopsies; CD117-, tryptase-, and CD25-stained)

2. Abnormal spindle-shaped morphology in $>25 \%$ of mast cells in marrow or other extracutaneous organ(s)

3. Abnormal mast cell expression of CD2 and/or CD25 (i.e., co-expression of CD117/CD25 or CD117/CD2)

4. Detection of genetic changes in mast cells from the blood, bone marrow, or extracutaneous organs for which an impact on the state of activity of affected mast cells in terms of an increased activity has been proven

5. Evidence (typically from body fluids such as whole blood, serum, plasma, or urine) of above-normal levels of mast cell mediators including:

- Tryptase in the blood

- Histamine or its metabolites (e.g., $N$-methylhistamine) in the urine

- Heparin in the blood

- Chromogranin A in the blood (potential confounders of cardiac or renal failure, neuroendocrine tumors, or recent proton pump inhibitor use were excluded)

- Other relatively mast cell-specific mediators (e.g., eicosanoids including prostaglandin $\mathrm{PGD}_{2}$, its metabolite $11-\beta-\mathrm{PGF}_{2 \alpha}$, or leukotriene E4)

6. Symptomatic response to inhibitors of mast cell activation or mast cell mediator production or action (e.g., histamine $\mathrm{H}_{1}$ and/or $\mathrm{H}_{2}$ receptor antagonists, cromolyn)

Diagnosis of MCAS made by either (1) the major criterion plus any one of the minor criteria or (2) any three minor criteria

in tyrosine kinase KIT, e.g., $\mathrm{KIT}^{\mathrm{D} 816 \mathrm{~V}}$ ) do not alter the morphology and immunohistochemistry of the surface of the affected MCs. Thus, in most cases except for patients with the reliably identifiable D816V mutation, it cannot be decided by simple tests whether MCs found in biopsies are genetically altered MCs or physiological MCs.

\section{First-line treatment options}

Step 1 in managing most situations of inappropriate MC activation is identifying the individual patient's unique triggers (chemical, physical, or otherwise) as precisely as possible and then desensitizing when possible (in truth, rarely) and otherwise practicing avoidance. With respect to drug treatment, only a few clinical therapeutic trials have been

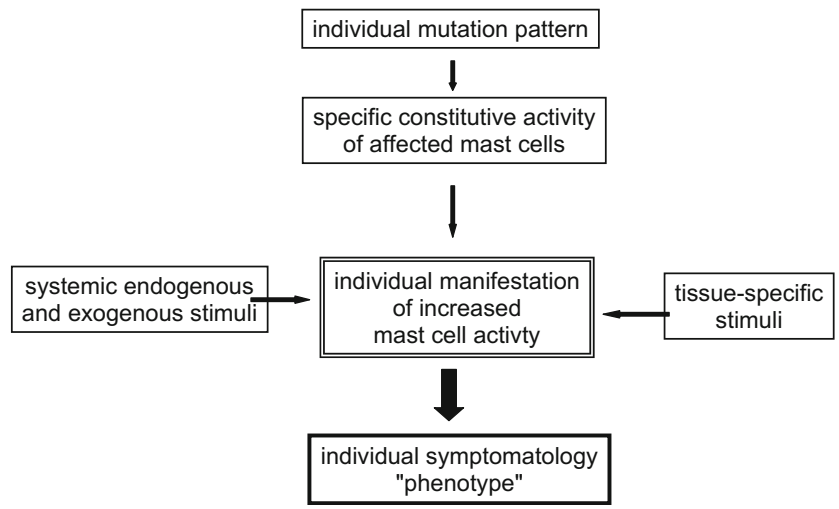

Fig. 2 Scheme of conditions responsible in MCAD for the development of individual phenotypes conducted in SM (midostaurin, cladribine, masitinib; Table 4), and there have been no therapeutic trials in MCAS yet. Most information about therapeutic effectiveness in MCAD has been found in small case series (Table 4) and single case reports, perhaps unsurprising given the mutational heterogeneity of the disease and thus the heterogeneity of its patterns of clinical presentation and therapeutic responsiveness. Therefore, in the future, it may be helpful to establish an international patient registry in partnership with existing registries so that issues related to molecular and clinical MCAD phenotypes can be adequately addressed. As the primary feature of MCAD is inappropriate MC activation (Molderings et al. 2011a, b; Pardanani 2013; Cardet et al. 2013), mainstays of first-line management are identification and avoidance of triggers plus therapies to control MC mediator production (both primary as well as secondary/reactive; Table 5) as well as their action (Table 6).

\section{Subordinate therapeutic options}

\section{Continuous diphenhydramine infusion}

Occasional patients suffer nearly continuous anaphylactoid and/or dysautonomic states poorly controlled by intermittently dosed epinephrine, antihistamines, and steroids. As discussed in more detail below, some such patients are particularly triggered by a wide range of medication excipients, making it challenging for them to tolerate trials of any adulterated (non-pure) medications, and yet some modicum of stability is required to pursue medication trials in such patients. 
Table 4 Case series and clinical therapeutic trials in systemic mastocytosis and mast cell activation syndrome

\begin{tabular}{ll}
\hline Compound & $\begin{array}{l}\text { Number of References } \\
\text { patients } \\
\text { included } \\
\text { in the study } \\
\text { or case series }\end{array}$ \\
\hline
\end{tabular}

$\mathrm{H}_{1}$-antihistamines

Rupatadine 30

Azelastine vs.

chlorpheniramine

Ketotifen vs.

hydroxyzine

Chlorpheniramine plus $\quad 8$

cimetidine

Continuous

diphenhydramine

infusion

Mast cell stabilizer

Cromoglicic acid

(cromolyn)

Kinase inhibitors

Imatinib (STI571)

20
22
17
12
5
3

Nilotinib (AMN107) 61

Dasatinib (BMS-354825) 33

4

Midostaurin (PKC412) 9

1

Masitinib

Cytostatic agents

Hydroxyurea

$\begin{array}{cl} & 5 \\ \text { Cladribine } & 22 \\ \text { (2-chlorodeoxyadenosine) } & 10\end{array}$

22

25

30

15

8

10

5

11

(2)

1

3

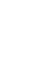

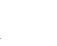

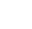

10

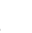

Siebenhaar et al. 2013

Friedman et al. 1993

Kettelhut et al. 1989

Frieri et al. 1985

Afrin $2015^{\mathrm{a}}$

Soter et al. 1979

Horan et al. 1990

Mallet et al. 1989

Frieri et al. 1985

Welch et al. 1983

Zachariae et al. 1981

Katoh et al. 1996

Droogendijk et al. 2006

Vega-Ruiz et al. 2009

Lim et al. 2009

Pagano et al. 2008

Pardanani et al. 2003

Heinrich et al. 2008

Hennessy et al. 2004

Hochhaus et al. 2015

Verstovsek et al. 2008

Purtill et al. 2008

Papayannidis et al. 2014

Knapper et al. 2011

Chandesris et al. 2014

Gotlib et al. 2014

Strati et al. 2015

Paul et al. 2010

Lim et al. 2009

Afrin $2013^{\mathrm{a}}$

Lim et al. 2009

Kluin-Nelemans et al. 2003

Pardanani et al. 2004

Pagano et al. 2008

Barete et al. 2015
Table 4 (continued)

\begin{tabular}{|c|c|c|}
\hline Compound & $\begin{array}{l}\text { Number of } \\
\text { patients } \\
\text { included } \\
\text { in the study } \\
\text { or case series }\end{array}$ & References \\
\hline \multicolumn{3}{|l|}{ Immunomodulation } \\
\hline \multirow[t]{8}{*}{ Interferon- $\alpha$} & 20 & Casassus et al. 2002 \\
\hline & 5 & Hauswirth et al. 2004 \\
\hline & 10 & Laroche et al. 2011 \\
\hline & 40 & Lim et al. 2009 \\
\hline & 8 & Pagano et al. 2008 \\
\hline & 6 & $\begin{array}{l}\text { Giraldo Castellano et al. } \\
1998\end{array}$ \\
\hline & 9 & Hennessy et al. 2004 \\
\hline & 3 & Worobec et al. 1996 \\
\hline Thalidomide & 16 & Gruson et al. 2013 \\
\hline \multicolumn{3}{|l|}{ IgE antibody } \\
\hline \multirow[t]{3}{*}{ Omalizumab } & 4 & Molderings et al. $2011 \mathrm{~b}^{\mathrm{a}}$ \\
\hline & 2 & Carter et al. 2007 \\
\hline & 2 & $\begin{array}{l}\text { Lieberoth and Thomsen } \\
2015\end{array}$ \\
\hline \multicolumn{3}{|l|}{ ß-Sympathomimetics } \\
\hline Isoprenaline, terbutaline & 5 & van Doormaal et al. 1986 \\
\hline \multicolumn{3}{|l|}{ Cyclooxygenase inhibitor } \\
\hline \multirow[t]{2}{*}{ Acetylsalicylic acid } & 4 & $\begin{array}{l}\text { Butterfield and Weiler } \\
2008\end{array}$ \\
\hline & 20 & Butterfield 2009 \\
\hline
\end{tabular}

${ }^{a}$ It indicates clinical trials performed with patients with mast cell activation syndrome

Diphenhydramine is a well-tolerated histamine $\mathrm{H}_{1}$ receptor blocker (that among other non-threatening adverse affects can cause dizziness and an increase in appetite) which can quickly suppress $\mathrm{MC}$ activation and is used to treat allergic reactions and anaphylaxis. However, its half-life is as short as $1 \mathrm{~h}$ (www.drugbank.ca/drugs/DB01075). Intermittently dosed, though, its initial therapeutic serum level rapidly declines to subtherapeutic levels and the patient seesaws into yet another flare. The safety of continuous diphenhydramine infusion was established in trials of the "BAD" regimen (diphenhydramine [Benadryl], lorazepam [Ativan], and dexamethasone) in refractory chemotherapy-induced emesis in adult and pediatric patients (Dix et al. 1999; Jones et al. 2007). In a small series of ten MCAS patients suffering almost continuous anaphylactoid/dysautonomic flares, continuous diphenhydramine infusion at $10-14.5 \mathrm{mg} / \mathrm{h}$ appeared effective in most patients at dramatically reducing flare rates and appeared safely sustainable at stable dosing for at least 21 months (Afrin 2015). Stabilization has enabled successful trials of other helpful medications, but no patient has yet successfully stopped continuous diphenhydramine infusion. 
Table 5 First-line drugs which can potentially be used in the treatment of mast cell (MC) activation disease and their target location and mechanisms of action

\section{Target location/mechanisms of action Growth Decrease of To relieve References} inhibition mediator release symptoms

\begin{tabular}{|c|c|c|c|c|}
\hline \multicolumn{5}{|l|}{ First-line drugs } \\
\hline $\begin{array}{l}\mathrm{H}_{1} \text {-antihistamines (preferably } \\
\text { of the second and third generations) }\end{array}$ & $\begin{array}{l}\text { Block mutual activation of mast cells via } \\
\mathrm{H}_{1} \text {-histamine receptors; antagonize } \\
\mathrm{H}_{1} \text {-histamine receptor-mediated } \\
\text { symptoms }\end{array}$ & $\mathrm{X}$ & $\mathrm{X}$ & $\begin{array}{l}\text { Church and Gradidge } \\
\quad 1980 \\
\text { Valent et al. 2007R } \\
\text { Picard et al. 2013R } \\
\text { Nurmatov et al. 2015 } \\
\text { Siebenhaar et al. 2013 } \\
\text { Escribano et al. 2006R }\end{array}$ \\
\hline $\mathrm{H}_{2}$-antihistamines & $\begin{array}{l}\text { Block mutual activation of mast cells } \\
\text { via } \mathrm{H}_{2} \text {-histamine receptors; antagonize } \\
\mathrm{H}_{2} \text {-histamine receptor-mediated } \\
\text { symptoms }\end{array}$ & $\mathrm{X}$ & $\mathrm{X}$ & $\begin{array}{l}\text { Valent et al. 2007R } \\
\text { Escribano et al. 2006R }\end{array}$ \\
\hline $\begin{array}{l}\text { Cromoglicic acid (also known } \\
\text { as cromolyn) }\end{array}$ & GPR35; modulation of chloride current & $\mathrm{X}$ & $\mathrm{X}$ & $\begin{array}{l}\text { Soter et al. } 1979 \\
\text { Valent et al. 2007R } \\
\text { Yang et al. 2010 } \\
\text { Edwards et al. } 2011 \\
\text { Edwards and Hagberg } \\
\quad 2010 \\
\text { Zhang et al. 2016 } \\
\text { Escribano et al. 2006R }\end{array}$ \\
\hline Vitamin C & $\begin{array}{l}\text { Increased degradation of histamine; } \\
\text { decrease of histamine formation by } \\
\text { inhibition of histidine decarboxylase }\end{array}$ & $\mathrm{X}$ & $\mathrm{X}$ & $\begin{array}{l}\text { Hagel et al. } 2013 \\
\text { Johnston et al. } 1992 \\
\text { Uchida et al. } 1989 \\
\text { Chatterjee et al. } 1975\end{array}$ \\
\hline
\end{tabular}

As a rule, these drugs should be used in combination to achieve a sufficient reduction of MC activity. All drugs should be tested for tolerance in a low single dose before therapeutic use, if their tolerance in the patient is not known from an earlier application. A precondition for therapeutic success is the avoidance of identifiable triggers of MC activation; in this context, parallel to the beginning of drug therapy, gluten, cow milk protein, and baker's yeast should be omitted from the diet for 3-4 weeks

$R$ review article (further references therein)

\section{Acute and chronic immunosuppressive therapies}

Though typically not first-line, acute and chronic immunosuppressive therapies can be considered (Fig. 3; Table 7) and may be particularly appropriate for patients possibly manifesting an autoimmune component of the disease as might be suggested by the presence, for example, of anti-IgE or anti-IgEreceptor antibodies. Glucocorticoids may exert beneficial effects in MCAD, including a decrease in production of stem cell factor (SCF, and possibly other cytokines) and a decrease in $\mathrm{MC}$ activation, by various mechanisms which have been extensively reviewed by Oppong et al. 2013. Glucocorticoids at doses $>20 \mathrm{mg}$ prednisone equivalent per day are frequently needed to effectively control otherwise refractory acute (and chronic) symptoms. Their chronic toxicity profile is disadvantageous for long-term use, but such toxicities have to be accepted in some cases. The influence of azathioprine, methotrexate, ciclosporine, hydroxyurea, and tamoxifen on $\mathrm{MC}$ activity can vary from no to moderate effect depending on individual disease factors. As in therapy of rheumatoid arthritis, azathioprine and methotrexate can be used in daily doses lower than those used in cancer or immunosuppressive posttransplant therapy. Effective MCAD therapy with ciclosporine requires doses as high as those used in transplantation medicine (M. Raithel, personal communication). Methotrexate has to be administered parenterally to be effective (unpublished observation, G.J. Molderings), and in the risk-benefit analysis, a possible non-immunologic histamine release from MCs (Estévez et al. 1996) has to be considered. Hence, use of the compound should be limited to MCAD with methotrexatesensitive comorbidities (e.g., rheumatoid arthritis and vasculitis).

Recently, the humanized anti-IgE murine monoclonal antibody omalizumab has been described in multiple case reports as safe and effective in MCAD (e.g., Molderings et al. 2011b; Kontou-Fili et al. 2010; Bell and Jackson 2012; Kibsgaard et al. 2014), though a definitive trial has yet to be conducted. Since treatment with omalizumab has an acceptable riskbenefit profile, it should be considered in cases of MCAD resistant to at least a few lines of therapy. The drug's expense likely consigns it to third-line (or later) treatment (Table 7). If elevated prostaglandin levels induce symptoms such as 
Table 6 Symptomatic treatment (orally as needed) in MCAD (modified from Molderings et al. 2014)

Colitis $\Rightarrow$ budesonide; for some days, prednisone $>20 \mathrm{mg} /$ day

Diarrhea $\Rightarrow \mathrm{c}(\mathrm{h})$ olestyramine; nystatin; montelukast; 5-HT 3 receptor inhibitors (e.g. ondansetron); incremental doses of acetylsalicylic acid (50-350 mg/ day; extreme caution because of the possibility to induce mast cell degranulation); in steps test each drug for 5 days until improvement of diarrhea

Colicky abdominal pain due to distinct meteorism $\Rightarrow$ metamizole; butylscopolamine

Angioedema $\Rightarrow$ tranexamic acid; icatibant

Nausea $\Rightarrow$ dimenhydrinate; lorazepam; 5- $\mathrm{HT}_{3}$ receptor inhibitors; NK1 antagonists such as aprepitant

Respiratory symptoms (mainly due to increased production of viscous mucus and obstruction with compulsive throat clearing) $\Rightarrow$ leukotriene receptor blockers such as montelukast; if in a country available, leukotriene synthesis inhibitors such as zileuton; urgent: short-acting $\beta$-sympathomimetic

Gastric complaints $\Rightarrow$ proton-pump inhibitors (de-escalating dose-finding)

Osteoporosis, osteolysis, bone pain $\Rightarrow$ bisphosphonates (vitamin D plus calcium application is second-line treatment in MCAD patients because of limited reported success and an increased risk for developing kidney and ureter stones); calcitonin; teriparatide (with caution; cases of cholestatic liver failure due to this drug have been reported); anti-RANKL drugs such as denosumab (dental clearance is required prior to treatment with bisphosphonates and anti-RANKL therapies due to risk for potentially severely morbid osteonecrosis of the jaw in patients with poor dentition or recent invasive dental work)

Non-cardiac chest pain $\Rightarrow$ when needed, additional dose of a $\mathrm{H}_{2}$-histamine receptor antagonist; also, proton-pump inhibitors for proven gastroesophageal reflux

Tachycardia $\Rightarrow \mathrm{AT}_{1}$-receptor antagonists; ivabradine

Neuropathic pain and paresthesia $\Rightarrow \alpha$-lipoic acid

Itches $\Rightarrow$ palmitoylethanolamine-containing care products; cromolyn-containing ointment

Rheumatoid symptoms $\Rightarrow$ COX2 inhibitors such as etoricoxib or celecoxib; paracetamol

Anemia $\Rightarrow$ in iron-deficiency anemia, iron supplementation (whether oral or parenteral) must be given cautiously due to risk for potentially intense mast cell activation; alternatively, red blood cell transfusion should be considered

Interstitial cystitis $\Rightarrow$ pentosan, amphetamines

Sleep-onset insomnia/sleep-maintenance insomnia $\Rightarrow$ triazolam

Conjunctivitis $\Rightarrow$ exclusion of a secondary disease; otherwise preservative-free eye drops with $\mathrm{H}_{1}$-antihistamine, cromolyn, ketotifen, or glucocorticoid for brief courses

Hypercholesterolemia $\Rightarrow$ (probably due to inhibition of transport into the cells, thus independent of diet) $>300 \mathrm{mg} / \mathrm{dL}$ therapeutic trial with HMG-CoA reductase inhibitor atorvastatin

persistent flushing, inhibition of cyclooxygenases by incremental doses of acetylsalicylic acid (ASA; 50-350 mg/day) may be used with extreme caution, since ASA can induce MC degranulation probably due its chemical property as an organic acid. The leukotriene antagonist montelukast (possibly more effective at twice-daily dosing; personal observation,
Fig. 3 Suggested treatment options for mast cell activation disease. All drugs should be tested for tolerance in a low single dose before therapeutic use, if their tolerance in the patient is not known from an earlier application. For further details of indication, see text
If $1^{\text {st }}$ line therapy is not sufficiently effective even at maximum doses, add:

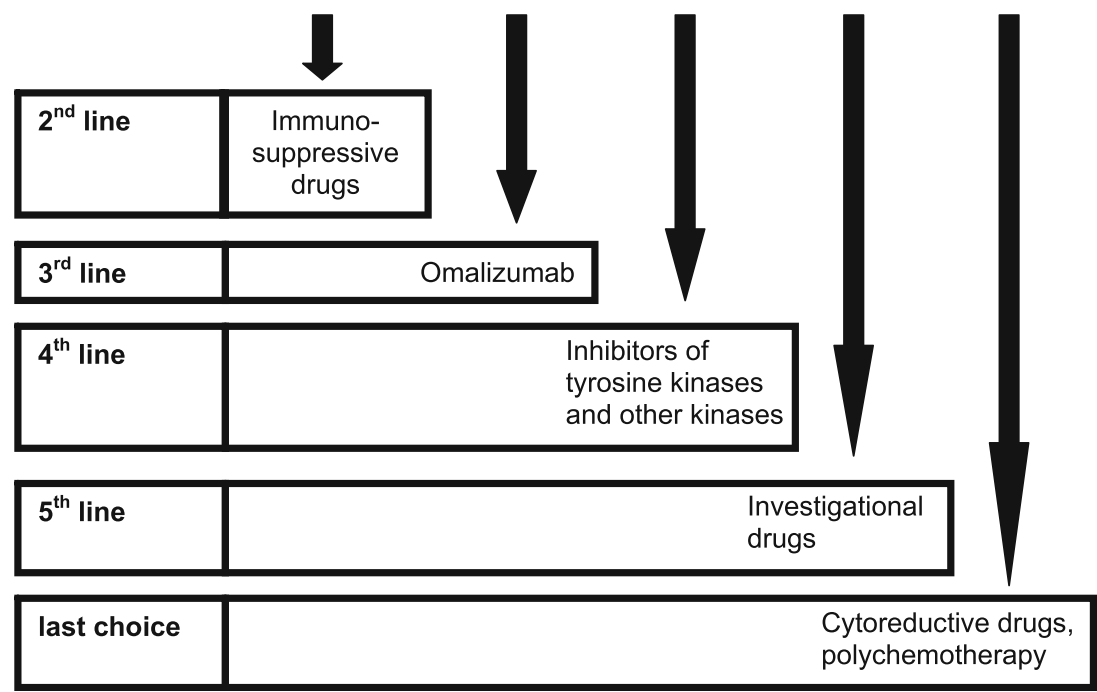


Table 7 Second- and third-line drugs which can potentially be used in the treatment of mast cell activation disease and their target location and mechanisms of action

\begin{tabular}{|c|c|c|c|c|c|}
\hline & $\begin{array}{l}\text { Target location/mechanisms } \\
\text { of action }\end{array}$ & $\begin{array}{l}\text { Growth } \\
\text { inhibition }\end{array}$ & $\begin{array}{l}\text { Decrease of } \\
\text { mediator release }\end{array}$ & To relieve symptoms & References \\
\hline Second-line drugs & Immunosuppressive drugs & & & & \\
\hline Azathioprine & Multiple targets & & $\mathrm{X}$ & $\mathrm{X}$ & $\begin{array}{l}\text { Nolte and Stahl Skov 1988, Own } \\
\text { unpublished data }\end{array}$ \\
\hline Ciclosporine & Calcineurin inhibitor & & $\mathrm{X}$ & $\mathrm{X}$ & $\begin{array}{l}\text { Kurosawa et al. 1999, Broyd et al. 2005, } \\
\text { Trojan and Khan 2012, Own } \\
\text { unpublished data }\end{array}$ \\
\hline Glucocorticoids & Multiple targets & $(\mathrm{X})$ & $\mathrm{X}$ & $\mathrm{X}$ & Zen et al. 2011R \\
\hline Hydroxyurea & Multiple targets & $\mathrm{X}$ & & $\mathrm{X}$ & Lim et al. 2009, Afrin 2013 \\
\hline Tamoxifen & $\begin{array}{l}\text { Precise mechanism of action } \\
\text { in MCAD unknown }\end{array}$ & $\mathrm{X}$ & $\mathrm{X}$ & In single cases & $\begin{array}{l}\text { Butterfield and Chen 2016, Duffy et al. } \\
\text { 2003; }\end{array}$ \\
\hline Methotrexate & Multiple targets & & $?$ & $\mathrm{X}$ & Sagi et al. 2011, Vrugt et al. 2000 \\
\hline \multicolumn{6}{|l|}{ Third-line drugs } \\
\hline Omalizumab & Anti-IgE antibody & & & $\mathrm{X}$ & $\begin{array}{l}\text { Molderings et al. 2011b } \\
\text { Bell and Jackson 2012; Kibsgaard et al. } \\
\quad 2014 \\
\text { Kontou-Fili et al. } 2010\end{array}$ \\
\hline $\begin{array}{l}\text { Etoricoxib } \\
\text { Acetylsalicylic acid }\end{array}$ & COX-inhibitors & & & $\mathrm{X}$ & $\begin{array}{l}\text { Butterfield and Weiler } 2008 \\
\text { Breslow et al. } 2009 \\
\text { Butterfield } 2009\end{array}$ \\
\hline Montelukast & Antagonist at cys- $\mathrm{LT}_{1}$ receptors & & & $\mathrm{X}$ & $\begin{array}{l}\text { Tolar et al. } 2004 \\
\text { Cikler et al. } 2009 \\
\text { Breslow et al. } 2009 \\
\text { Turner et al. } 2012\end{array}$ \\
\hline Zileuton & 5-Lipoxygenase inhibitor & & & $\mathrm{X}$ & Rodriguez et al. 2011 \\
\hline
\end{tabular}

$R$ review article (further references therein)

L.B. Afrin) and the 5-lipoxygenase inhibitor zileuton may be useful adjuvants in people with MCAD, particularly in those with refractory gastrointestinal and urinary symptoms (Tolar et al. 2004; Turner et al. 2012; Akhavein et al. 2012).

Studies of kinase inhibitors, both on-market (e.g., imatinib, nilotinib, dasatinib) and experimental (e.g., midostaurin, masitinib), have yielded variable responses in SM ranging from no response to partial or even complete responses (Fig. 3; Table 8). As with all drugs used in therapy of MCAD, their therapeutic success seems to be strongly dependent on the individual patient, again underscoring the observed mutational heterogeneity of the disease. In formal studies in SM patients, although some kinase inhibitors reduced $\mathrm{MC}$ burden as reflected by histological normalization in bone marrow and improved laboratory surrogate markers (e.g., tryptase level in blood), at best only partial improvement of mediator-related symptoms was achieved (Droogendijk et al. 2006; Gotlib et al. 2008; Verstovsek et al. 2008; Vega-Ruiz et al. 2009). There has been repeated suggestion that symptoms in MCAD may be due more to mediator release from normal MCs secondarily activated by pathologically overactive, mutated MCs (Galli and Costa 1995; Rosen and Goetzl 2005; Boyce 2007; Kaneko et al. 2009; Fig. 2 in Molderings et al.
2014), helping to explain why intensity and pattern of symptoms do not correlate with degree of $\mathrm{MC}$ proliferation and infiltration (Topar et al. 1998; Hermine et al. 2008; BroesbyOlsen et al. 2013; Erben et al. 2014; Quintás-Cardama et al. 2013). Distinction in pathways in the MC which promote MC proliferation vs. mediator production/release may explain why kinase inhibitors reduce MC burdens and MC-driven symptoms to different degrees (Droogendijk et al. 2006; Gotlib et al. 2008; Verstovsek et al. 2008; Vega-Ruiz et al. 2009; Table 8). However, in some case reports, kinase inhibitors have been significantly effective at relieving symptoms. Thus, in spite of potential serious adverse effects of these drugs, a therapeutic trial may be justified in individual cases at an early stage. Partial and complete responses have been reported with some of these agents in MCAS too (e.g., Afrin 2010, 2011, 2012, 2015; Afrin et al. 2015a). Dosing of the kinase inhibitors in the individual often is considerably lower than how such drugs are dosed for other applications (e.g., imatinib, sunitinib; Afrin et al. 2015a). Possibly due to the causative mutations in multiple genes leading to simultaneous activation of multiple intracellular pathways, multitargeted kinase inhibitors such as midostaurin and sunitinib may be more effective than 
Table 8 Kinase inhibitors which can potentially be used as fourth-line drugs in the treatment of mast cell activation disease and their target location and mechanisms of action

\begin{tabular}{|c|c|c|c|c|c|}
\hline & Target location/mechanisms of action & $\begin{array}{l}\text { Growth } \\
\text { inhibition }\end{array}$ & $\begin{array}{l}\text { Decrease of } \\
\text { mediator } \\
\text { release }\end{array}$ & To relieve symptoms & References \\
\hline Fourth-line drugs & \multicolumn{5}{|l|}{ Inhibitors of tyrosine kinases and other kinases } \\
\hline Imatinib & $\begin{array}{l}\text { KIT (excluding D816X), PDGFR, } \\
\text { Bcr-Abl, Arg/Abl2, DDR-1 }\end{array}$ & $\mathrm{X}$ & $(\mathrm{X})$ & $\mathrm{X}$ & $\begin{array}{l}\text { Pardanani et al. } 2003 \\
\text { Droogendijk et al. } 2006 \\
\text { Lim et al. } 2009 \\
\text { Vega-Ruiz et al. } 2009 \\
\text { Aman et al. } 2012 \\
\text { Vaali et al. } 2012 \\
\text { Quintás-Cardama et al. 2011R } \\
\text { Marton et al. } 2015\end{array}$ \\
\hline Nilotinib & KIT, PDGFR, Bcr-Abl & $\mathrm{X}$ & & $(\mathrm{X})$ & $\begin{array}{l}\text { Hochhaus et al. } 2006 \\
\text { Quintás-Cardama et al. 2011R } \\
\text { Hochhaus et al. } 2015 \\
\text { El-Agamy } 2012\end{array}$ \\
\hline Dasatinib & KIT, BCR-ABL1, Lyn, Btk, Tec & $\mathrm{X}$ & & $(\mathrm{X})$ & $\begin{array}{l}\text { Verstovsek et al. } 2008 \\
\text { Hantschel et al. } 2007 \\
\text { Gleixner et al. } 2011 \\
\text { Quintás-Cardama et al. 2011R }\end{array}$ \\
\hline Sunitinib & $\begin{array}{l}\text { VEGFR, PDGFR, KIT, FLT3, RET, } \\
\text { CSF1R, SRC, } \\
313 \text { potential kinase targets }\end{array}$ & $\mathrm{X}$ & $\mathrm{X}$ & $\mathrm{X}$ & $\begin{array}{l}\text { Afrin et al. 2015a } \\
\text { Yamaki and Yoshino } 2012 \\
\text { Papaetis and Syrigos } 2009 \\
\text { Bairlein } 2010\end{array}$ \\
\hline Masitinib & KIT, PDGFR $\alpha$, Lck, LYN, FGFR3, FAK & $\mathrm{X}$ & & $\mathrm{X}$ & $\begin{array}{l}\text { Marech et al. } 2014 \\
\text { Moussy and Kinet } 2014 \\
\text { Paul et al. } 2010 \\
\text { Quintás-Cardama et al. 2011R }\end{array}$ \\
\hline Midostaurin & PKC, FLT3, KIT, PDGFR, VEGFR2 & $\mathrm{X}$ & $\mathrm{X}$ & $\mathrm{X}$ & $\begin{array}{l}\text { Gotlib et al. } 2014 \\
\text { Papayannidis et al. } 2014 \\
\text { Knapper et al. } 2011 \\
\text { Quintás-Cardama et al. 2011R }\end{array}$ \\
\hline Ponatinib & Bcr-Abl, KIT, FLT3, FGFR1, PDGFR $\alpha$, Lyn & $\mathrm{X}$ & & & $\begin{array}{l}\text { Jin et al. } 2014 \\
\text { Gleixner et al. } 2013\end{array}$ \\
\hline Bafetinib & KIT (excluding D816X), Abl, Lyn & $\mathrm{X}$ & & & Peter et al. 2010a \\
\hline Bosutinib & Lyn, Btk & $\mathrm{X}$ & & In ASM patients ineffective & $\begin{array}{l}\text { Gleixner et al. } 2011 \\
\text { Randall et al. } 2015\end{array}$ \\
\hline
\end{tabular}

$R$ review article (further references therein)

drugs which selectively downregulate only one intracellular pathway.

In the mastocytosis patient with significant MC burden and/or an aggressive clinical course, cytoreductive drugs are prescribed (Lim et al. 2009; Valent et al. 2010). Unfortunately, effective cytoreductive therapies in SM presently are few in number and typically offer only modest response rates, qualities, and durations. Cytoreductive options include interferon- $\alpha$ and 2-chlorodeoxyadenosine (cladribine, 2CdA; Fig. 3 and Table 9). Interferon- $\alpha$ is frequently combined with prednisone and is commonly used as cytoreductive therapy for aggressive SM. It ameliorates mastocytosis-related organopathy in a proportion of cases but can be associated with considerable adverse effects (e.g., flu-like symptoms, myelosuppression, depression, hypothyroidism), which may limit its use in MCAD (Simon et al. 2004; Butterfield 2005). PEGylated interferon- $\alpha$ has been shown to be as efficacious as and less toxic than the non-PEGylated form in some myeloproliferative neoplasms, but it has not been specifically studied in MCAD. 2-Chlorodeoxyadenosine is generally reserved for last-choice treatment of patients with aggressive SM who are either refractory or intolerant to interferon- $\alpha$. Potential toxicities of 2-CdA include significant and potentially prolonged myelosuppression and lymphopenia with increased risk for opportunistic infections.

\section{Last resorts}

Polychemotherapy, including intensive induction regimens of the kind used in treating acute myeloid leukemia, as well as 
Table 9 Last-choice drugs which can potentially be used in the treatment of mast cell activation disease and their target location and mechanisms of action. R-review article (further references therein)

\begin{tabular}{|c|c|c|c|c|c|}
\hline & $\begin{array}{l}\text { Target location/mechanisms } \\
\text { of action }\end{array}$ & Growth inhibition & $\begin{array}{l}\text { Decrease of } \\
\text { mediator release }\end{array}$ & $\begin{array}{l}\text { To relieve } \\
\text { symptoms }\end{array}$ & References \\
\hline \multicolumn{6}{|l|}{ Last-choice drugs } \\
\hline Interferon- $\alpha$ & Multiple targets & $\mathrm{X}$ & & $(\mathrm{X})$ & $\begin{array}{l}\text { Simon et al. } 2004 \\
\text { Casassus et al. } 2002 \\
\text { Hauswirth et al. } 2004 \\
\text { Butterfield et al. 2005 } \\
\text { Butterfield 2005R } \\
\text { Yoshida et al. 2009 } \\
\text { Lim et al. 2009 } \\
\text { Quintás-Cardama et al. 2011R }\end{array}$ \\
\hline Cladribine & Nucleoside analog & $\mathrm{X}$ & $\mathrm{X}$ & $\mathrm{X}$ & $\begin{array}{l}\text { Tefferi et al. } 2001 \\
\text { Kluin-Nelemans et al. } 2003 \\
\text { Pardanani et al. } 2004 \\
\text { Lim et al. } 2009 \\
\text { Böhm et al. } 2010 \\
\text { Radojković et al. } 2011 \\
\text { Quintás-Cardama et al. 2011R } \\
\text { Lock et al. } 2015 \\
\text { Barete et al. } 2015\end{array}$ \\
\hline
\end{tabular}

high-dose therapy with stem cell rescue, are approaches restricted to rare, selected patients. Allogeneic stem cell transplantation sometimes yields remissions in mastocytosis long thought impermanent (Spyridonidis et al. 2004; Nakamura et al. 2006; Bae et al. 2013; Gromke et al. 2013), though recent data may offer new hope (Ustun et al. 2014).

\section{Investigational drugs}

There are several drugs approved for indications other than MCAD which already have been successfully used in isolated cases with MCAD (Table 10). In cases of unsuccessful first- to fourth-line therapy, these compounds may be considered as treatment options.

A variety of drugs have been shown to inhibit $\mathrm{MC}$ growth, to decrease MC mediator release, and/or to relieve mediatorinduced symptoms in in vitro and in vivo animal models (Table 11). Some of these drugs are approved for certain indications (such as ambroxol, statins, mefloquine, and ruxolitinib) and, thus, may be used (if accessible given financial considerations for some agents) if MCAD patients suffer from both the disorder of indication (e.g., hypercholesterolemia - statins, mucous congestion - ambroxol, polycythemia vera - ruxolitinib) and MCAD. An important question is what the role of the other compounds without approved indications should be in clinical practice. There are several challenges that may hamper the clinical introduction of novel targeted therapies in general. Some of these challenges include inherent problems in the translation of preclinical findings to the clinic, the presence of multiple coactive deregulated pathways in the disease, and questions related to the optimal design of clinical trials (e.g., eligibility criteria and endpoints). In particular, the testing of novel targeted treatment in an isolated fashion may be problematic and may in fact underestimate the effectiveness of these novel compounds. It is reasonable to assume that combination therapy will be the key to target parallel critical pathways.

\section{General considerations on drug treatment of MCAD}

Although no biomarkers of symptomaticity or therapeutic response are yet validated, the tolerability and efficacy of most therapies tried in MCAD (starting, and escalating in dosage and composition, cautiously) become clinically evident within 1-2 months. Modest experiments with alternative dosages and/or dosing frequencies are not unreasonable. Therapies clearly shown clinically helpful should be continued; therapies not meeting this high bar should be halted to avoid the troublesome polypharmacy that can easily develop in such patients. With no predictors of response yet available, a costbased approach to sequencing therapeutic trials in a given patient seems reasonable. It is not even clear yet that medications targeted at mediators found elevated in diagnostic testing (e.g., antihistamines in patients with elevated histamine, nonsteroidal anti-inflammatory drugs in patients with elevated prostaglandins, leukotriene inhibitors in patients with elevated leukotrienes) are reliably effective, again perhaps unsurprising given the multitude of MC mediators and the complexity of the signaling networks dysregulated by the multiple mutations in $\mathrm{MC}$ regulatory elements present in most MCAD patients. Successful regimens appear highly personalized. 
Table 10 Drugs successfully (or not) used off-label to treat isolated cases of mast cell activation disease

\begin{tabular}{|c|c|c|c|c|c|}
\hline & $\begin{array}{l}\text { Target location/mechanisms of } \\
\text { action }\end{array}$ & $\begin{array}{l}\text { Growth } \\
\text { inhibition }\end{array}$ & $\begin{array}{l}\text { Decrease of } \\
\text { mediator } \\
\text { release }\end{array}$ & To relieve symptoms & References \\
\hline \multicolumn{6}{|l|}{ Investigational drugs } \\
\hline Thalidomide & $\begin{array}{l}\text { Precise mechanism } \\
\text { of action unknown }\end{array}$ & & & $\mathrm{X}$ & $\begin{array}{l}\text { Damaj et al. } 2008 \\
\text { Gruson et al. } 2013\end{array}$ \\
\hline Lenalidomide & & & & No effect & Kluin-Nelemans et al. 2009 \\
\hline $\begin{array}{l}\text { Flavonoids (e.g., } \\
\text { luteolin, quercetin, } \\
\text { genistein) }\end{array}$ & Multiple & $\mathrm{X}$ & $(\mathrm{X})$ & $(\mathrm{X})$ & $\begin{array}{l}\text { Alexandrakis et al. } 2003 \\
\text { Kempuraj et al. } 2006 \\
\text { Min et al. } 2007 \\
\text { Finn and Walsh 2013R } \\
\text { Weng et al. } 2012 \\
\text { Lee et al. } 2015 \\
\text { Weng et al. } 2015\end{array}$ \\
\hline Miltefosine & Raft modulator & & $\mathrm{X}$ & $(\mathrm{X})$ & $\begin{array}{l}\text { Weller et al. } 2009 \\
\text { Maurer et al. 2013R }\end{array}$ \\
\hline Mepolizumab & IL-5 antibody & $\mathrm{X}$ & & & Otani et al. 2012 \\
\hline Rituximab & CD20 antibody & & & $\mathrm{X}$ & Borzutzky et al. 2014 \\
\hline Ruxolitinib & JAK & $\mathrm{X}$ & & $\mathrm{X}$ & $\begin{array}{l}\text { Yacoub and Prochaska } \\
2016 \\
\text { Kvasnicka et al. } 2014\end{array}$ \\
\hline Cannabinoids & $\begin{array}{l}\text { Agonists at the } \\
\text { cannabinoid receptors }\end{array}$ & & & $\mathrm{X}$ & $\begin{array}{l}\text { De Filippis et al. } 2008 \\
\text { Frenkel et al. } 2015 \\
\text { Own unpublished } \\
\quad \text { experiences }\end{array}$ \\
\hline Methylene blue & Guanylyl cyclase inhibitor & & & Anaphylaxis treatment & $\begin{array}{l}\text { Rodrigues et al. } 2007 \\
\text { Evora and Simon 2007R }\end{array}$ \\
\hline Pimecrolimus & Calcineurin inhibitor & $\mathrm{X}$ & & $\begin{array}{l}\text { Cutaneous symptoms; } \\
\text { (mice) }\end{array}$ & $\begin{array}{l}\text { Ma et al. } 2010 \\
\text { Correia et al. } 2010\end{array}$ \\
\hline Everolimus & mTOR & & & no effect & Parikh et al. 2010 \\
\hline Ribavirin & $\begin{array}{l}\text { Possibly suppression of activated } \\
\text { retroviral elements in the } \\
\text { genome which may be } \\
\text { involved in the development of } \\
\text { the somatic mutations in KIT } \\
\text { and other proteins }\end{array}$ & & $\mathrm{X}$ & $\mathrm{X}$ & $\begin{array}{l}\text { Marquardt et al. } 1987 \\
\text { Molderings } 2016 \\
\text { Own unpublished } \\
\quad \text { experiences }\end{array}$ \\
\hline
\end{tabular}

$R$ review article (further references therein)

Multiple simultaneous (or nearly so) changes in the medication regimen are discouraged since such can confound identification of the specific therapy responsible for a given improvement (or deterioration). Ineffective or harmful agents should be stopped promptly. Prescribers should be aware that although rapid demonstration of intolerance of a new medication (or a new formulation of a previously well-tolerated medication) often suggests excipient reactivity as further discussed below, some active drug molecules themselves (e.g., cromolyn) sometimes cause an initial symptom flare which usually soon abates. Temporary waiver of gluten-, yeast-, and cow milk protein-containing foods during the initial 3-4 weeks of drug therapy can improve the response rate (Biesiekierski et al. 2011; Rodrigo et al. 2013; own unpublished experiences). When MCAD is suspected, therapies that strongly activate the immune system (e.g., vaccinations with live vaccines or autohemotherapy) must be given with caution (especially if similar therapies were previously already poorly tolerated), as such interventions sometimes dramatically worsen MCAD acutely and/or chronically.

Any drug can induce intolerance symptoms in the individual MCAD patient. In some MCAD patients, the disease creates such remarkable states of not only constitutive MC activation but also aberrant $\mathrm{MC}$ reactivity that such patients unfortunately experience a great propensity to react adversely to a wide variety of medication triggers. Those MCAD patients begin demonstrating (either acutely or subacutely) odd/unusual/weird/strange/bizarre/unexpected symptoms soon after beginning new medications. It is very important to note that such patients often demonstrate even a greater propensity to react to 


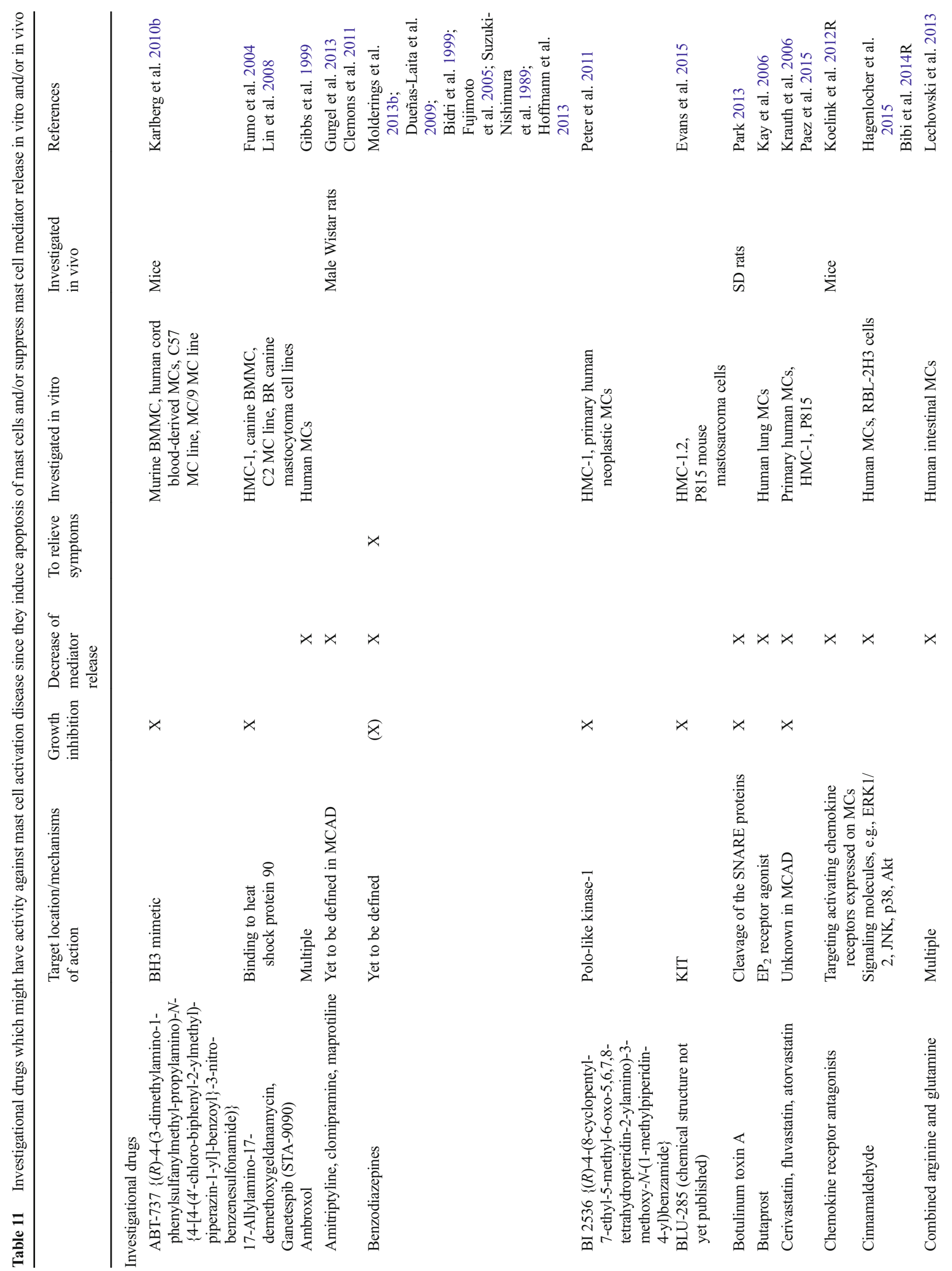




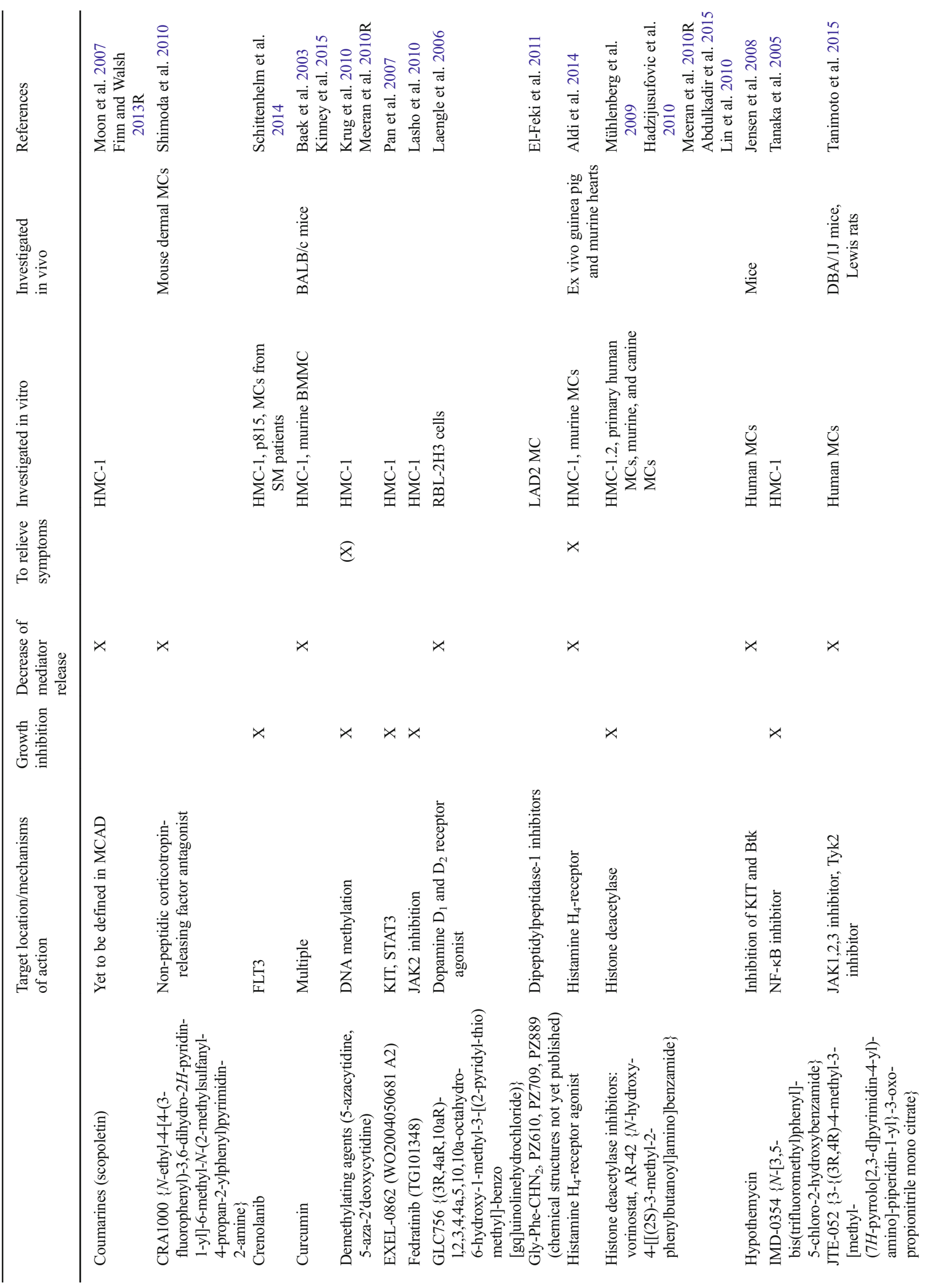




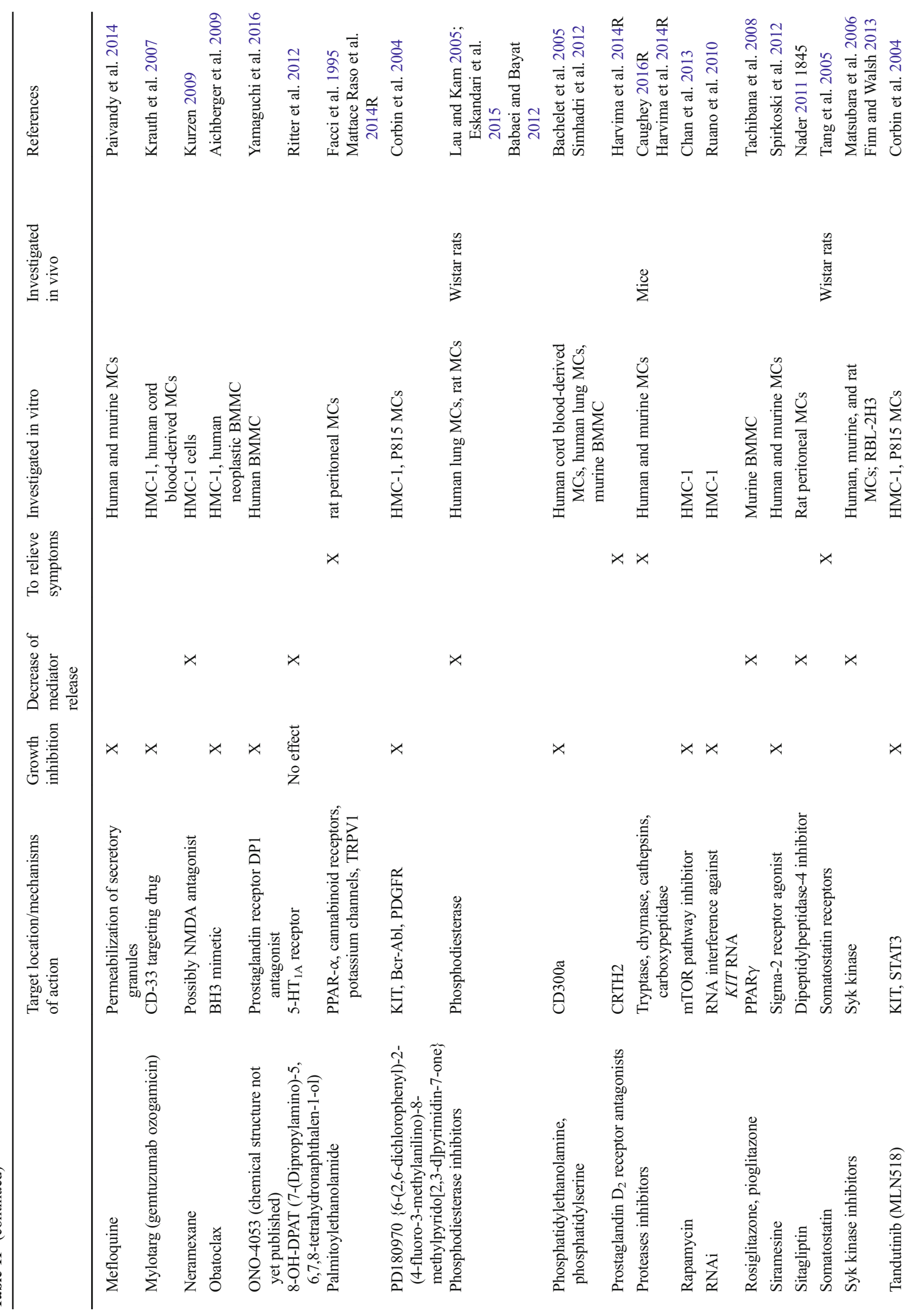




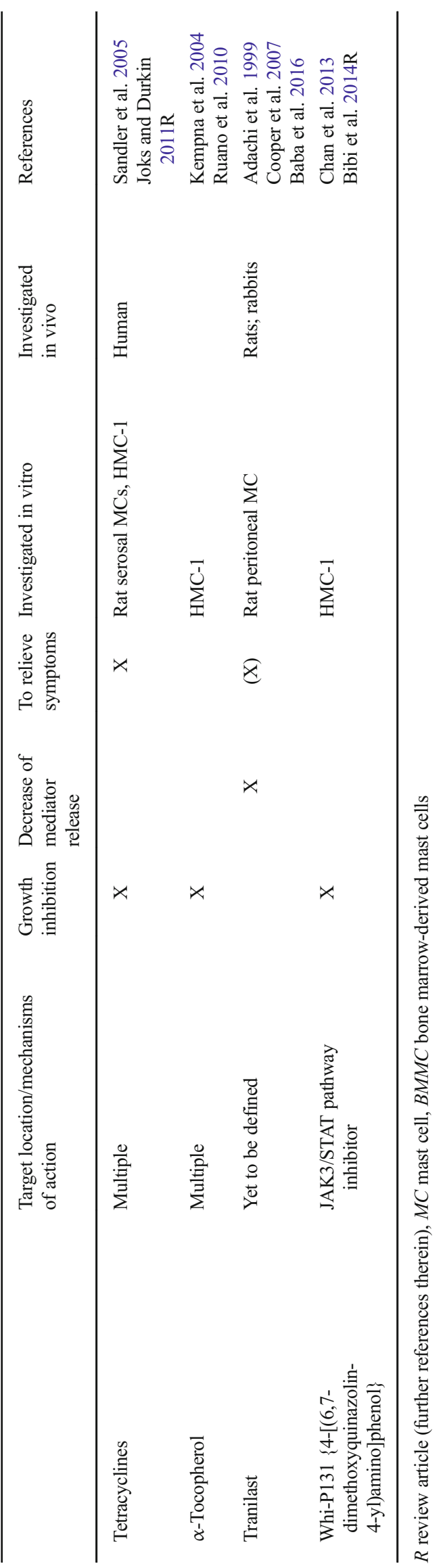


Table 12 Compilation of drugs associated with a high risk of release of mediators from mast cells and their therapeutic alternatives (compiled from Mousli et al. 1994; Sido et al. 2014; Afrin et al. 2015b; McNeil et al. 2015)

\begin{tabular}{|c|c|c|}
\hline Substance group & $\begin{array}{l}\text { Drugs with proven or theoretical high risk } \\
\text { of mast cell activation }\end{array}$ & Therapeutic alternatives \\
\hline Intravenous narcotics & $\begin{array}{l}\text { Methohexital } \\
\text { Phenobarbital } \\
\text { Thiopental }\end{array}$ & $\begin{array}{l}\text { Propofol } \\
\text { Ketamine } \\
\text { Etomidate } \\
\text { Midazolam }\end{array}$ \\
\hline Muscle relaxants & $\begin{array}{l}\text { Atracurium } \\
\text { Mivacurium } \\
\text { Rocuronium }\end{array}$ & $\begin{array}{l}\text { Cis-atracurium } \\
\text { Vecuronium }\end{array}$ \\
\hline Antibiotics & $\begin{array}{l}\text { Cefuroxim } \\
\text { Gyrase inhibitors } \\
\text { Vancomycin }\end{array}$ & Roxithromycin \\
\hline $\begin{array}{l}\text { Selective dopamine- and } \\
\text { norepinephrine reuptake inhibitors }\end{array}$ & Bupropion & Amitriptyline, doxepine, clomipramine, maprotiline \\
\hline Selective serotonin reuptake inhibitors & All & \\
\hline Anticonvulsive agents & Carbamazepine, topiramate & Clonazepam \\
\hline Opioid analgesics & meperidine, morphine, codeine & remifentanil, alfentanil, fentanyl, oxycodon, piritramid \\
\hline Peripheral-acting analgesics & $\begin{array}{l}\text { Acidic non-steroidal anti-inflammatory } \\
\text { drugs such as ASS or ibuprofen }\end{array}$ & Paracetamol, metamizol \\
\hline Local anesthetics & $\begin{array}{l}\text { Amide-type: lidocaine } \\
\text { articaine } \\
\text { Ester-type: tetracaine, } \\
\text { procaine }\end{array}$ & prefer amide-Type, e.g., bupivacaine \\
\hline Peptidergic drugs & $\begin{array}{l}\text { Icatibant, cetrorelix, sermorelin, octreotide, } \\
\text { leuprolide }\end{array}$ & \\
\hline $\mathrm{X}$-ray contrast medium & $\begin{array}{l}\text { Iodinated contrast medium } \\
\text { Gadolinium chelate }\end{array}$ & $\begin{array}{l}\text { Non-ionic contrast media: iohexol, iopamidol, iopromida, } \\
\text { ioxilan, ioversol, idolatran, iodixanol }\end{array}$ \\
\hline Plasma substitutes & $\begin{array}{l}\text { Hydroxyethyl starch } \\
\text { Gelatine }\end{array}$ & Albumin solution, $0.9 \%-\mathrm{NaCl}$ solution, Ringer's solution \\
\hline Cardiovascular drugs & $\begin{array}{l}\text { ACE inhibitors } \\
\text { ß-Adrenoceptor antagonists }\end{array}$ & Sartans, calcium channel antagonists, ivabradine, and much else \\
\hline
\end{tabular}

medication excipients (i.e., fillers, binders, dyes, preservatives) than to the active ingredients. When the patient tries one or more alternative formulations of a medication with the same active ingredient but sharing as few as possible (preferably none) of the excipients in the offending formulation, the patient may discover the medication to be at least tolerable and perhaps even quite effective. Furthermore, such a scenario obviously provides the patient (and physician and pharmacist) a great opportunity to identify one or more of the specific excipients which are triggering abnormal reactivity in the patient's dysfunctional MCs, and it is those specific excipientsnot the medication as a whole - that should be added to the patient's allergy list and screened against all present medications being taken by the patient and against all future medications proposed for the patient. An MCAD patient's physician would be wise to not assume, just because an excipient is very widely used in many medication products and appears innocuous and well tolerated in the vast majority of patients, that the same excipient will necessarily be tolerated well in MCAD patients (unpublished observation of the authors). Sometimes the specificity of the reaction is quite extraordinary. For example, patients who react to wood-based microcrystalline cellulose might tolerate cotton-based microcrystalline cellulose without any difficulty at all, or vice versa. In some cases, the pharmacist is unable to identify alternative commercially available formulations sharing few to none of the excipients in the offending formulation, and in those cases, a compounding pharmacist may need to be engaged to identify/develop a custom-compounded formulation the patient can tolerate. (There can be geographic and financial challenges in accessing compounding pharmacies, though.) Occasionally, MCAD patients may be so remarkably reactive to such a wide range of excipients that they can only tolerate a given medication when provided as pure drug salt, reconstituted in water (without preservatives). Intolerance symptoms can be mediated by $\operatorname{IgE}$ antibodies, though this scenario appears to be rare since the symptoms are usually not ameliorated by the antiIgE monoclonal antibody omalizumab (unpublished observation, G.J. Molderings). Alternatively, they may be mediated by $\mathrm{IgG}$ antibodies, raising the question of whether gamma globulin (if itself tolerable) might be a helpful adjunct therapy in such patients (perhaps by directly targeting the MC surface's IgG receptors or via 
Table 13 Schematic summary of selected potential targets of pharmacological interventions in MCAD

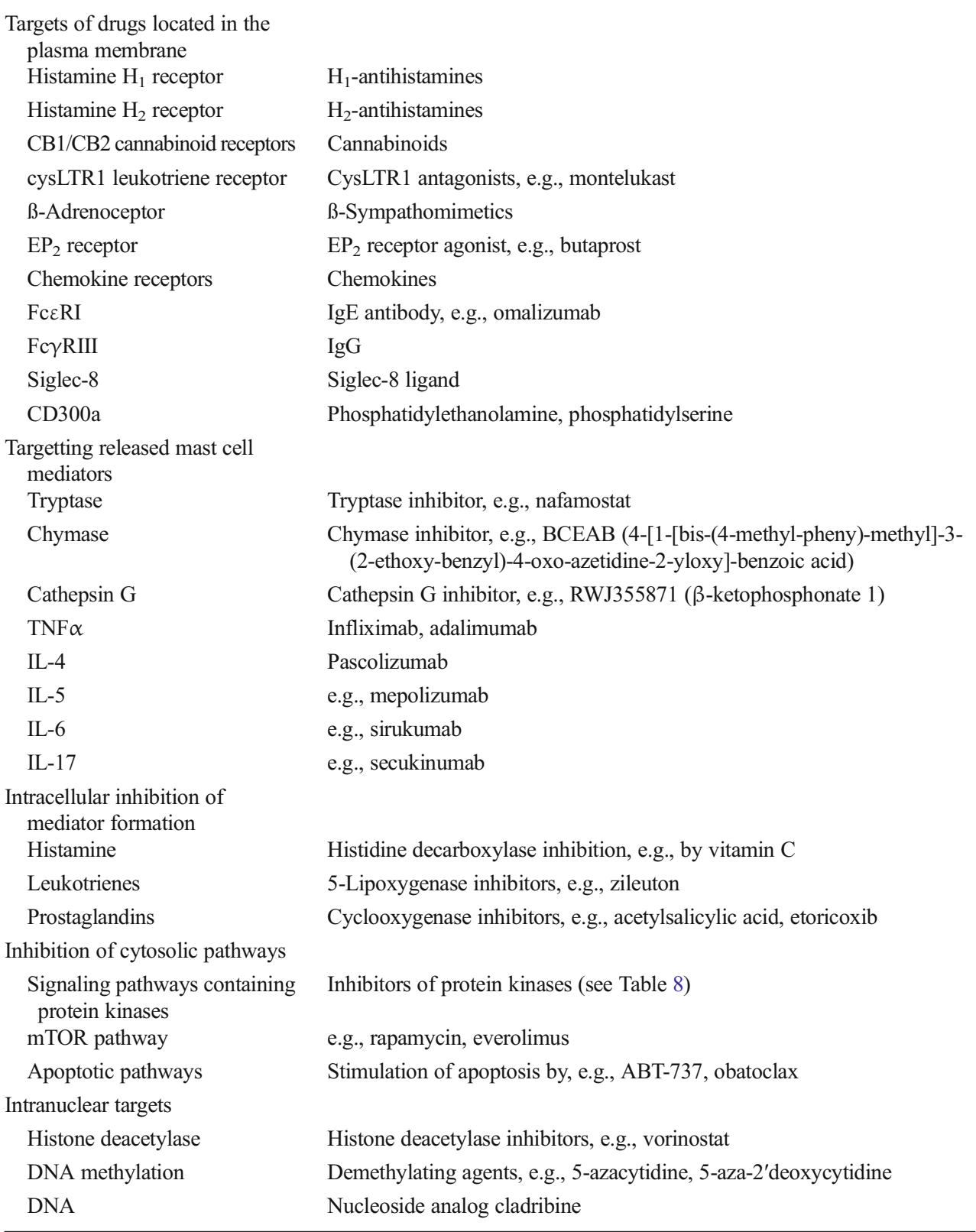

indirect pathways). Recently, a MC-specific receptor termed MRGPRX2 has been identified which appears to be crucially involved in pseudo-allergic drug reactions (McNeil et al. 2015; Seifert 2015).

\section{Drugs which should not be used in MCAD}

Several drugs have the ability to trigger MC mediator release. A compilation of drugs known to be associated with a high risk of release of mediators from MCs is given in Table 12. However, there often are therapeutic alternatives to these drugs (Table 12).

\section{Conclusions and future perspectives}

The therapeutic management of individuals with MCAD is complex and requires reviewing the entire spectrum of symptoms. The paucity of randomized, controlled studies makes treatment of refractory disease challenging and requires patience, persistence, and a methodical approach on the parts of both patient and managing provider(s). Delayed control of the symptoms may increase morbidity. Effective therapy often consists simply of antihistamines and MC-stabilizing compounds supplemented with medications targeted at specific symptoms and complications (Table 13). Current treatment options for refractory disease are based mainly on 
observational studies and case reports. Until larger randomized, controlled trials become available to give more guidance on therapy for refractory disease, clinicians should use the available data in conjunction with their clinical expertise and the adverse effect profile of the available drugs to make treatment decisions. More research is certainly needed to better understand MCAD pathobiology, in particular to determine which deregulated genes contribute to a specific symptom or symptom cluster. The greatest challenge in translational research for the discovery of new rational therapies requires a highly interactive interdisciplinary approach engaging basic science labs and clinicians. Understanding of the key components might hasten the progress of novel treatment for all these devastating MCAD phenotypes.

Acknowledgments The publication of this article was financially supported by the Förderclub Mastzellforschung e.V.

Open Access This article is distributed under the terms of the Creative Commons Attribution 4.0 International License (http:// creativecommons.org/licenses/by/4.0/), which permits unrestricted use, distribution, and reproduction in any medium, provided you give appropriate credit to the original author(s) and the source, provide a link to the Creative Commons license, and indicate if changes were made.

\section{References}

Abdulkadir H, Grootens J, Kjellander M, Hellstram Lindberg E, Nilsson G, Ungerstedt J (2015) Histone deacetylase inhibitor SAHA mediates epigenetic silencing of KIT D816V mutated systemic mastocytosis primary mast cells and selective apoptosis of mutated mast cells. Blood; 126: abstract 2834

Adachi S, Maruyama T, Kondo T, Todoroki T, Fukao K (1999) The prevention of postoperative intraperitoneal adhesions by tranilast: N-(3',4'-dimethoxycinnamoyl)anthranilic acid. Surg Today 29:5154

Afrin LB (2010) Mast cell activation disorder masquerading as pure red cell aplasia. Int J Hematol 91:907-908

Afrin LB (2011) Polycythemia from mast cell activation syndrome: lessons learned. Am J Med Sci 342:44-49

Afrin LB (2012) Mast cell activation syndrome masquerading as agranulocytosis. Mil Med 177:113-117

Afrin LB (2013) Utility of hydroxyurea in mast cell activation syndrome. Exp Hematol Oncol 2:28

Afrin LB (2015) Utility of continuous diphenhydramine infusion in severe mast cell activation syndrome. Blood 126:5194 abstract

Afrin LB, Molderings GJ (2014) A concise, practical guide to diagnostic assessment for mast cell activation disease. World J Hematol 3:1-17

Afrin LB, Cichocki FM, Patel K, Molderings GJ (2015a) Successful treatment of mast cell activation syndrome with sunitinib. Eur J Haematol 95:595-597

Afrin LB, Pöhlau D, Raithel M, Haenisch B, Dumoulin FL, Homann J, Mauer UM, Harzer S, Molderings GJ (2015b) Mast cell activation disease: an underappreciated cause of neurologic and psychiatric symptoms and diseases. Brain Behav Immun 50:314-321

Aichberger KJ, Gleixner KV, Mirkina I, Cerny-Reiterer S, Peter B, Ferenc V, Kneidinger M, Baumgartner C, Mayerhofer M, Gruze A, Pickl WF, Sillaber C, Valent P (2009) Identification of proapoptotic Bim as a tumor suppressor in neoplastic mast cells: role of KIT D816V and effects of various targeted drugs. Blood 114:5342-5351
Akhavein A, Patel NR, Minoyappa PK, Glover SC (2012) Allergic mastocytic gastroenteritis and colitis: an unexplained etiology in chronic abdominal pain and gastrointestinal dysmotility. Gastroenterol Res Pract 2012:950582

Akin C, Valent P, Metcalfe D (2010) Mast cell activation syndrome: proposed diagnostic criteria. J Allergy Clin Immunol 126:10991104

Aldi S, Takano KI, Tomita K, Koda K, Chan NY, Marino A, SalazarRodriguez M, Thurmond RL, Levi R (2014) Histamine H4receptors inhibit mast cell renin release in ischemia/reperfusion via PKC E-dependent aldehyde dehydrogenase type-2 activation. J Pharmacol Exp Ther 349:508-517

Alexandrakis MG, Kyriakou DS, Kempuraj D, Huang M, Boucher W, Seretakis D, Theoharides TC (2003) The isoflavone genistein inhibits proliferation and increases histamine content in human leukemic mast cells. Allergy Asthma Proc 24:373-377

Aman J, van Bezu J, Damanafshan A, Huveneers S, Eringa EC, Vogel SM, Groeneveld AB, Vonk Noordegraaf A, van Hinsbergh VW, van Nieuw Amerongen GP (2012) Effective treatment of edema and endothelial barrier dysfunction with imatinib. Circulation 126: 2728-2738

Anand P, Singh B, Jaggi AS, Singh N (2012) Mast cells: an expanding pathophysiological role from allergy to other disorders. Naunyn Schmiedeberg's Arch Pharmacol 385:657-670

Baba A, Tachi M, Ejima Y, Endo Y, Toyama H, Matsubara M, Saito K, Yamauchi M, Miura C, Kazama I (2016) Anti-allergic drugs tranilast and ketotifen dose-dependently exert mast cell-stabilizing properties. Cell Physiol Biochem 38:15-27

Babaei S, Bayat M (2012) Effect of pentoxifylline administration on mast cell numbers and degranulation in a diabetic and normoglycemic rat model wound healing. Iran Red Crescent Med J 14:483-487

Bachelet I, Munitz A, Moretta A, Moretta L, Levi-Schaffer F (2005) The inhibitory receptor IRp60 (CD300a) is expressed and functional on human mast cells. J Immunol 175:7989-7995

Bae MH, Kim HK, Park CJ, Seo EJ, Park SH, Cho YU, Jang S, Chi HS, Lee KH (2013) A case of systemic mastocytosis associated with acute myeloid leukemia terminating as aleukemic mast cell leukemia after allogeneic hematopoietic stem cell transplantation. Ann Lab Med 33:125-129

Baek OS, Kang OH, Choi YA, Choi SC, Kim TH, Nah YH, Kwon DY, Kim YK, Kim YH, Bae KH, Lim JP, Lee YM (2003) Curcumin inhibits protease-activated receptor-2 and -4-mediated mast cell activation. Clin Chim Acta 338:135-141

Bairlein M (2010) Characterization of the small molecule kinase inhibitor SU11248 (sunitinib/SUTENT) in vitro and in vivo-towards response prediction in cancer therapy with kinase inhibitors. TU Munich, Munich, Germany, Medical thesis

Barete S, Lortholary O, Damaj G, Hirsch I, Chandesris MO, Elie C, Hamidou M, Durieu I, Suarez F, Grosbois B, Limal N, Gyan E, Larroche C, Guillet G, Kahn JE, Casassus P, Amazzough K, Coignard-Biehler H, Georgin-Lavialle S, Lhermitte L, Fraitag S, Canioni D, Dubreuil P, Hermine O (2015) Long-term efficacy and safety of cladribine (2-CdA) in adult patients with mastocytosis. Blood 126:1009-1016

Bell MC, Jackson DJ (2012) Prevention of anaphylaxis related to mast cell activation syndrome with omalizumab. Ann Allergy Asthma Immunol 108:383-384

Bibi S, Arslanhan MD, Langenfeld F, Jeanningros S, Cerny-Reiterer S, Hadzijusufovic E, Tchertanov L, Moriggl R, Valent P, Arock M (2014) Co-operating STAT5 and AKT signaling pathways in chronic myeloid leukemia and mastocytosis: possible new targets of therapy. Haematologica 99:417-429

Bidri M, Royer B, Averlant G, Bismuth G, Guillosson JJ, Arock M (1999) Inhibition of mouse mast cell proliferation and proinflammatory mediator release by benzodiazepines. Immunopharmacology 43:75-86 
Biesiekierski JR, Newnham ED, Irving PM, Barrett JS, Haines M, Doecke JD, Shepherd SJ, Muir JG, Gibson PR (2011) Gluten causes gastrointestinal symptoms in subjects without celiac disease: a double-blind randomized placebo-controlled trial. Am J Gastroenterol 106:508-514

Böhm A, Sonneck K, Gleixner KV, Schuch K, Pickl WF, Blatt K, Peter B, Herrmann H, Schernthaner GH, Pehamberger H, Rabitsch W, Sperr WR, Valent $P$ (2010) In vitro and in vivo growth-inhibitory effects of cladribine on neoplastic mast cells exhibiting the imatinibresistant KIT mutation D816V. Exp Hematol 38:744-755

Borzutzky A, Morales PS, Mezzano V, Nussbaum S, Burks W (2014) Induction of remission of frequent idiopathic anaphylaxis with rituximab. AAAAI Meeting 28.2.-04.03, abstract 91

Boyce JA (2007) Mast cells and eicosanoid mediators: a system of reciprocal paracrine and autocrine regulation. Immunol Rev 217:168185

Breslow RG, Caiado J, Castells MC (2009) Acetylsalicylic acid and montelukast block mast cell mediator-related symptoms during rapid desenesitization. Ann Allergy Asthma Immunol 102:155-160

Broesby-Olsen S, Kristensen T, Vestergaard H, Brixen K, Møller MB, Bindslev-Jensen C, Mastocytosis Centre Odense University Hospital (MastOUH) (2013) KIT D816V mutation burden does not correlate to clinical manifestations of indolent systemic mastocytosis. J Allergy Clin Immunol 132:723-728

Broyd H, Koffer A, Assem ESK (2005) Effect of cyclosporin-A on secretion from intact and permeabilised mast cells. Inflamm Res 54(Supplement 1):7-8

Butterfield JH (2005) Interferon treatment for hypereosinophilic syndromes ans systemic mastocytosis. Acta Haematol 114:26-40

Butterfield JH (2009) Survey of aspirin administration in systemic mastocytosis. Prostaglandins Other Lipid Mediat 88:122-124

Butterfield JH, Chen D (2016) Response of patients with indolent systemic mastocytosis to tamoxifen citrate. Leuk Res 40:10-16

Butterfield JH, Weiler CR (2008) Prevention of mast cell activation disorder-associated clinical sequelae of excessive prostaglandin D(2) production. Int Arch Allergy Immunol 147:338-343

Butterfield JH, Tefferi A, Kozuh GF (2005) Successful treatment of systemic mastocytosis with high- dose interferon-alfa: long-term follow-up of a case. Leuk Res 29:131-134

Cardet JC, Akin C, Lee MJ (2013) Mastocytosis: update on pharmacotherapy and future directions. Expert Opin Pharmacother 14:20332045

Carter MC, Robyn JA, Bressler PB, Walker JC, Shapiro GG, Metcalfe DD (2007) Omalizumab for the treatment of unprovoked anaphylaxis in patients with systemic mastocytosis. J Allergy Clin Immunol 119:1550-1551

Casassus P, Caillat-Vigneron N, Martin A, Simon J, Gallais V, Beaudry P, Eclache V, Laroche L, Lortholary P, Raphaël M, Guillevin L, Lortholary O (2002) Treatment of adult systemic mastocytosis with interferon-alpha: results of a multicentre phase II trial on 20 patients. Br J Haematol 119:1090-1097

Caughey GH (2016) Mast cell proteases as pharmacological targets. Eur J Pharmacol 778:44-55

Chan IJ, Kasprowicz S, Tharp MD (2013) Distinct signalling pathways for mutated KIT(V560G) and KIT(D816V) in mastocytosis. Clin Exp Dermatol 38:538-544

Chandesris MO, Damaj G, Canioni D, Brouzes C, Cabaret L, Hanssens K, Durieu I, Durupt S, Besnard S, Beyne-Rauzy O, Launay D, Schiffmann A, Niault M, Ranta D, Agape P, Faure C, Chantepie SP, Daguindau N, Bourgeet P, Dubreuil P, Lortholary O, Hermine O (2014) Treatment of advanced systemic mastocytosis with PKC412: the French compassionate use programme experience and historical comparison. ASH Meeting, abstract 3193

Chatterjee IB, Gupta SD, Majumder AK, Nandi BK, Subramanian N (1975) Effect of ascorbic acid on histamine metabolism in scorbutic guinea-pigs. J Physiol 251:271-279
Church MK, Gradidge CF (1980) Inhibition of histamine release from human lung in vitro by antihistamines and related drugs. $\mathrm{Br} \mathrm{J}$ Pharmacol 69:663-667

Cikler E, Ersoy Y, Cetinel S, Ercan F (2009) The leukotriene d4 receptor antagonist, montelukast, inhibits mast cell degranulation in the dermis induced by water avoidance stress. Acta Histochem 111:112118

Clemons A, Vasiadi M, Kempuraj D, Kourelis T, Vandoros G, Theoharides TC (2011) Amitriptyline and prochlorperazine inhibit proinflammatory mediator release from human mast cells: possible relevance to chronic fatigue syndrome. J Clin Psychopharmacol 31: 385-387

Cohen SS, Skovbo S, Vestergaard H, Kristensen T, Møller M, Bindslev-Jensen C, Fryzek JP, Broesby-Olsen S (2014) Epidemiology of systemic mastocytosis in Denmark. Br J Haematol 166:521-528

Cooper K, Young J, Wadsworth S, Cui H, diZerega GS, Rodgers KE (2007) Reduction of post-surgical adhesion formation with tranilast. J Surg Res 141:153-161

Corbin AS, Griswold IJ, La Rosée P, Yee KW, Heinrich MC, Reimer CL, Druker BJ, Deininger MW (2004) Sensitivity of oncogenic KIT mutants to the kinase inhibitors MLN518 and PD180970. Blood 104:3754-3757

Correia O, Duarte AF, Quirino P, Azevedo R, Delgado L (2010) Cutaneous mastocytosis: two pediatric cases treated with topical pimecrolimus. Dermatol Online J 16:8

Damaj G, Bernit E, Ghez D, Claisse JF, Schleinitz N, Harlé JR, Canioni $\mathrm{D}$, Hermine $\mathrm{O}$ (2008) Thalidomide in advanced mastocytosis. Br J Haematol 141:249-253

De Filippis D, D’Amico A, Iuvone T (2008) Cannabinomimetic control of mast cell mediator release: new perspective in chronic inflammation. J Neuroendocrinol 20(Suppl 1):20-25

Dix S, Cord M, Howard S, Coon J, Belt R, Geller R (1999) Safety and efficacy of a continuous infusion, patient controlled anti-emetic pump to facilitate outpatient administration of high-dose chemotherapy. Bone Marrow Transplant 24:561-566

Droogendijk HJ, Kluin-Nelemans HJC, van Doormaal JJ, Oranje AR, van de Loosdrecht AA, van Daele PLA (2006) Imatinibmesylate in the treatment of systemic mastocytosis: a phase II trial. Cancer 107:345-351

Dueñas-Laita A, Ruiz-Muñoz P, Armentia A, Pinacho F, MartínArmentia B (2009) Successful treatment of chronic drug-resistant urticaria with alprazolam. J Allergy Clin Immunol 123:504-505

Duffy SM, Lawley WJ, Kaur D, Yang W, Bradding P (2003) Inhibition of human mast cell proliferation and survival by tamoxifen in association with ion channel modulation. J Allergy Clin Immunol 112:965972

Edwards AM, Hagberg H (2010) Oral and inhaled sodium cromoglicate in the management of systemic mastocytosis: a case report. J Med Case Rep 4:193

Edwards AM, Stevens MT, Church MK (2011) The effects of topical sodium cromoglicate on itch and flare in human skin induced by intradermal histamine: a randomised double-blind vehicle controlled intra-subject design trial. BMC Res Notes 4:47

El-Agamy DS (2012) Anti-allergic effects of nilotinib on mast cellmediated anaphylaxis like reactions. Eur J Pharmacol 680:115-121

El-Feki G, X Zhou, LC Lau, J Pedersen, AF Walls (2011) Inhibitors of dipeptidyl peptidase I (DPPI) as mast cell stabilising agents: the contribution of DPPI in mast cell activation. J Allergy Clin Immunol 127, Suppl. - Abstracts

Erben P, Schwaab J, Metzgeroth G, Horny HP, Jawhar M, Sotlar K, Fabarius A, Teichmann M, Schneider S, Ernst T, Müller MC, Giehl M, Marx A, Hartmann K, Hochhaus A, Hofmann WK, Cross NC, Reiter A (2014) The KIT D816V expressed allele burden for diagnosis and disease monitoring of systemic mastocytosis. Ann Hematol 93:81-88 
Escribano L, Akin C, Castells M, Schwartz LB (2006) Current options in the treatment of mast cell mediator-related symptoms in mastocytosis. Inflamm Allergy Drug Targets 5:61-77

Eskandari N, Bastan R, Peachell PT (2015) Regulation of human skin mast cell histamine release by PDE inhibitors. Allergol Immunopathol (Madr) 43:37-41

Estévez MD, Vieytes MR, Botana LM (1996) Mitoxantrone induces nonimmunological histamine release from rat mast cells. Inflamm Res 45:113-117

Evans E, Gardino A, Hodous B, Davis A, Zhu J, Kohl NE, Lengauer C (2015) Blu-285, a potent and selective inhibitor for hematologic malignancies with KIT exon 17 mutations. ASH Annual Meeting: abstract 568

Evora PR, Simon MR (2007) Role of nitric oxide production in anaphylaxis and its relevance for the treatment of anaphylactic hypotension with methylene blue. Ann Allergy Asthma Immunol 99:306-313

Facci L, Dal Toso R, Romanello S, Buriani A, Skaper SD, Leon A (1995) Mast cells express a peripheral cannabinoid receptor with differential sensitivity to anandamide and palmitoylethanolamide. Proc Natl Acad Sci U S A 92:3376-3380

Finn DF, Walsh JJ (2013) Twenty-first century mast cell stabilisers. Br J Pharmacol 170:23-37

Frenkel A, Roy-Shapira A, Evgeni B, Leonid K, Borer A, Klein M (2015) Life threatening idiopathic recurrent angioedema responding to cannabis. Case Rep Immunol 2015:780824

Friedman BS, Santiago ML, Berkebile C, Metcalfe DD (1993) Comparison of azelastine and chlorpheniramine in the treatment of mastocytosis. J Allergy Clin Immunol 92:520-526

Frieri M, Alling DW, Metcalfe DD (1985) Comparison of the therapeutic efficacy of cromolyn sodium with that of combined chlorpheniramine and cimetidine in systemic mastocytosis. Results of a double-blind clinical trial. Am J Med 78:9-14

Fujimoto T, Nishiyama T, Hanaoka K (2005) Inhibitory effects of intravenous anesthetics on mast cell function. Anesth Analg 101:1054 1059

Fumo G, Akin C, Metcalfe DD, Neckers L (2004) 17-Allylamino-17demethoxygeldanamycin (17-AAG) is effective in downregulating mutated, constitutively activated KIT protein in human mast cells. Blood 103:1078-1084

Galli SJ, Costa JJ (1995) Mast-cell-leukocyte cytokine cascades in allergic inflammation. Allergy 50:851-862

Gibbs BF, Schmutzler W, Vollrath IB, Brosthardt P, Braam U, Wolff HH, Zwadlo-Klarwasser G (1999) Ambroxol inhibits the release of histamine, leukotrienes and cytokines from human leukocytes and mast cells. Inflamm Res 48:86-93

Giraldo Castellano P, García-Erce JA, Alvarez Alegret R, Arroyo Rubio A, Mayayo Artal P, Vicente Cámara P, Rubio-Félix D, Giralt RM (1998) Interferon alpha and systemic mastocytosis. Analysis of therapeutic efficacy in 6 cases. Rev Clin Esp 198:345-350

Gleixner KV, Mayerhofer M, Cerny-Reiterer S, Hörmann G, Rix U, Bennett KL, Hadzijusufovic E, Meyer RA, Pickl WF, Gotlib J, Horny HP, Reiter A, Mitterbauer-Hohendanner G, Superti-Furga G, Valent P (2011) KIT-D816V-independent oncogenic signaling in neoplastic cells in systemic mastocytosis: role of Lyn and Btkactivation and disruption by dasatinib and bosutinib. Blood 118: 1885-1898

Gleixner KV, Peter B, Blatt K, Suppan V, Reiter A, Radia D, Hadzijusufovic E, Valent P (2013) Synergistic growth-inhibitory effects of ponatinib and midostaurin (PKC412) on neoplastic mast cells carrying KIT D816V. Haematologica 98:1450-1457

Gotlib J, George TI, Corless C, Linder A, Ruddell A, Akin C, DeAngelo DJ, Kepten I, Lanza C, Heinemann H, Yin O, Gallagher N, Graubert T (2008) The KIT tyrosine kinase inhibitor midostaurine (PKC412) exhibits a high response rate in aggressive systemic mastocytosis (ASM): interim results of a phase II trial. Blood 110:1039A
Gotlib J, Kluin-Neelemans HC, George TI et al. (2014) Midostaurin (PKC412) demonstrates a high rate of durable responses in patients with advanced systemic mastocytosis: results from the fully accrued global phase 2 CPKC412D2201 trial. Blood;124: ASH Annual Meeting Abstracts; Abstract 636

Gri G, Frossi B, D’Inca F, Danelli L, Betto E, Mion F, Sibilano R, Pucillo C (2012) Mast cell: an emerging partner in immune interaction. Front Immunol 3:120

Gromke T, Elmaagacli AH, Ditschkowski M, Hegerfeldt Y, Koldehoff M, Hlinka M, Ottinger H, Trenschel R, Beelen DW (2013) Delayed graft-versus-mast-cell effect on systemic mastocytosis with associated clonal haematological non-mast cell lineage disease after allogeneic transplantation. Bone Marrow Transplant 48:732-733

Gruson B, Lortholary O, Canioni D, Chandesris O, Lanternier F, Bruneau J, Grosbois B, Livideanu C, Larroche C, Durieu I, Barete S, Sevestre H, Diouf M, Chaby G, Marolleau JP, Dubreuil P, Hermine O, Damaj G (2013) Thalidomide in systemic mastocytosis: results from an open-label, multicentre, phase II study. Br J Haematol 161:434-442

Gurgel JA, Lima-Júnior RC, Rabelo CO, Pessoa BB, Brito GA, Ribeiro RA (2013) Amitriptyline, clomipramine, and maprotiline attenuate the inflammatory response by inhibiting neutrophil migration and mast cell degranulation. Rev Bras Psiquiatr 35:387-392

Hadzijusufovic E, Peter B, Herrmann H, Schuch, Thaiwong T, Yuzbasiyan-Gurkan V, Pickl W, Willmann M, Valent P (2010) Mutations in KIT predict resistance to several TKI (sorafenib, sunitinib, and masitinib) in neoplastic human and canine mast cell lines. Haematologica 95(suppl.2):357 abs. 0857

Haenisch B, Nöthen MM, Molderings GJ (2012) Systemic mast cell activation disease: the role of molecular genetic alterations in pathogenesis, heritability and diagnostics. Immunology 137:197-205

Haenisch B, Fröhlich H, Herms S, Molderings GJ (2014) Evidence for contribution of epigenetic mechanisms in the pathogenesis of systemic mast cell activation disease. Immunogenetics 66:287-297

Hagel AF, Layritz CM, Hagel WH, Hagel HJ, Hagel E, Dauth W, Kressel J, Regnet T, Rosenberg A, Neurath MF, Molderings GJ, Raithel M (2013) Intravenous infusion of ascorbic acid decreases serum histamine concentrations in patients with allergic and non-allergic diseases. Naunyn Schmiedeberg's Arch Pharmacol 386:789-793

Hagenlocher Y, Kießling K, Schäffer M, Bischoff SC, Lorentz A (2015) Cinnamaldehyde is the main mediator of cinnamon extract in mast cell inhibition. Eur J Nutr 54:1297-1309

Hamilton MJ, Hornick JL, Akin C, Castells MC, Greenberger NJ (2011) Mast cell activation syndrome: a newly recognized disorder with systemic clinical manifestations. J Allergy Clin Immunol 128:147152

Hantschel O, Rix U, Schmidt U, Bürckstümmer T, Kneidinger M, Schütze G, Colinge J, Bennett KL, Ellmeier W, Valent P, SupertiFurga G (2007) The Btk tyrosine kinase is a major target of the BcrAbl inhibitor dasatinib. Proc Natl Acad Sci U S A 104:13283-13288

Harvima IT, Levi-Schaffer F, Draber P, Friedman S, Polakovicova I, Gibbs BF, Blank U, Nilsson G, Maurer M (2014) Molecular targets on mast cells and basophils for novel therapies. J Allergy Clin Immunol 134:530-544

Hauswirth AW, Simonitsch-Klupp I, Uffmann M, Koller E, Sperr WR, Lechner K, Valent P (2004) Response to therapy with interferon alpha- $2 \mathrm{~b}$ and prednisolone in aggressive systemic mastocytosis: report of five cases and review of the literature. Leuk Res 28:249-257

Heinrich MC, Joensuu H, Demetri GD, Corless CL, Apperley J, Fletcher JA, Soulieres D, Dirnhofer S, Harlow A, Town A, McKinley A, Supple SG, Seymour J, Di Scala L, van Oosterom A, Herrmann R, Nikolova Z, McArthur AG, Imatinib Target Exploration Consortium Study B2225 (2008) Phase II, open-label study evaluating the activity of imatinib in treating life-threatening malignancies known to be associated with imatinib-sensitive tyrosine kinases. Clin Cancer Res $14: 2717-2725$ 
Hennessy B, Giles F, Cortes J, O'brien S, Ferrajoli A, Ossa G, GarciaManero G, Faderl S, Kantarjian H, Verstovsek S (2004) Management of patients with systemic mastocytosis: review of $\mathrm{M}$. D. Anderson Cancer Center experience. Am J Hematol 77:209-214

Hermine O, Lortholary O, Leventhal PS, Catteau A, Soppelsa F, Baude C, Cohen-Akenine A, Palmérini F, Hanssens K, Yang Y, Sobol H, Fraytag S, Ghez D, Suarez F, Barete S, Casassus P, Sans B, Arock M, Kinet JP, Dubreuil P, Moussy A (2008) Case-control cohort study of patients' perceptions of disability in mastocytosis. PLoS One 3:e2266

Hochhaus A, Ottmann OG, Lauber S, Hughes T, Verhoef G, Schwarer AP, Gratwohl A, Rafferty T, Resta D, Gattermann N (2006) A phase II study of nilotinib, a novel inhibitor of c-Kit, PDGFR, and Bcr$\mathrm{Abl}$, administered to patients with systemic mastocytosis. Blood 108: Abstract 2703 [ASH Annual Meeting Abstracts]

Hochhaus A, Baccarani M, Giles FJ, le Coutre PD, Müller MC, Reiter A, Santanastasio H, Leung M, Novick S, Kantarjian HM (2015) Nilotinib in patients with systemic mastocytosis: analysis of the phase 2, open-label, single-arm nilotinib registration study. J Cancer Res Clin Oncol 141:2047-2060

Hoffmann K, Xifró RA, Hartweg JL, Spitzlei P, Meis K, Molderings GJ, von Kügelgen I (2013) Inhibitory effects of benzodiazepines on the adenosine $\mathrm{A}(2 \mathrm{~B})$ receptor mediated secretion of interleukin- 8 in human mast cells. Eur J Pharmacol 700:152-158

Horan RF, Sheffer AL, Austen KF (1990) Cromolyn sodium in the management of systemic mastocytosis. J Allergy Clin Immunol 85:852855

Ibelgaufts H. (2016.) "Mast Cells" in COPE: cytokines and cells online pathfinder encyclopaedia, Available at http://www.cells-talk.com (accessed March 21, 2016)

Jensen BM, Beaven MA, Iwaki S, Metcalfe DD, Gilfillan A (2008) Concurrent inhibition of KIT- and FceRI-mediated signaling: coordinated suppression of mast cell activation. J Pharmacol Exp Ther 324:128-138

Jin B, Ding K, Pan J (2014) Ponatinib induces apoptosis in imatinibresistant human mast cells by dephosphorylating mutant D816V KIT and silencing beta-catenin signaling. Mol Cancer Ther 13: $1217-1230$

Johnston CS, Martin LJ, Cai X (1992) Antihistamine effect of supplemental ascorbic acid and neutrophil chemotaxis. J Am Coll Nutr 11: 172-176

Joks R, Durkin HG (2011) Non-antibiotic properties of tetracyclines as anti-allergy and asthma drugs. Pharmacol Res 64:602-609

Jones E, Koyama T, Ho RH, Kuttesch J, Shankar S, Whitlock JA, Cartwright J, Frangoul H (2007) Safety and efficacy of a continuous infusion, patient-controlled antiemetic pump for children receiving emetogenic chemotherapy. Pediatr Blood Cancer 48: 330-332

Kaneko I, Suzuki K, Matsuo K, Kumagai H, Owada Y, Noguchi N, Hishinuma T, Ono M (2009) Cysteinyl leukotrienes enhance the degranulation of bone marrow-derived mast cells through the autocrine mechanism. Tohoku J Exp Med 217:185-191

Karlberg M, Ekoff M, Labi V, Strasser A, Huang D, Nilsson G (2010a) Pro-apoptotic Bax is the major and Bak an auxiliary effector in cytokine deprivation-induced mast cell apoptosis. Cell Death Dis $1: \mathrm{e} 43$

Karlberg M, Ekoff M, Huang DC, Mustonen P, Harvima IT, Nilsson G (2010b) The BH3-mimetic ABT-737 induces mast cell apoptosis in vitro and in vivo: potential for therapeutics. J Immunol 185: 2555-2562

Katoh N, Hirano S, Yasuno H (1996) Solitary mastocytoma treated with tranilast. J Dermatol 23:335-339

Kay LJ, Yeo WW, Peachell PT (2006) Prostaglandin E-2 activates EP2 receptors to inhibit human lung mast cell degranulation. Br J Pharmacol 147:707-713
Kempna P, Reiter E, Arocks M, Azzi A, Zingg JM (2004) Inhibition of HMC-1 mast cell proliferation by vitamin E. J Biol Chem 279: 50700-50709

Kempuraj D, Castellani ML, Petrarca C, Frydas S, Conti P, Theoharides TC, Vecchiet J (2006) Inhibitory effect of quercetin on tryptase and inetrleukin- 6 release, and histidine decarboxylase mRNA transcription by human mast cell-1 cell line. Clin Exp Med 6:150-156

Kettelhut BV, Berkebile C, Bradley D, Metcalfe DD (1989) A doubleblind, placebo-controlled, crossover trial of ketotifen versus hydroxyzine in the treatment of pediatric mastocytosis. J Allergy Clin Immunol 83:866-870

Kibsgaard L, Skjold T, Deleuran M, Vestergaard C (2014) Omalizumab induced remission of idiopathic anaphylaxis in a patient suffering from indolent systemic mastocytosis. Acta DermVenereol 94:363364

Kinney SR, Carlson L, Ser-Dolansky J, Thompson C, Shah S, Gambrah A, Xing W, Schneider SS, Mathias CB (2015) Curcumin ingestion inhibits mastocytosis and suppresses intestinal anaphylaxis in a murine model of food allergy. PLoS One 10:e0132467

Kluin-Nelemans HC, Oldhoff JM, Van Doormaal JJ, Van’t Wout JW, Verhoef G, Gerrits WB, van Dobbenburgh OA, Pasmans SG, Fijnheer R (2003) Cladribine therapy for systemic mastocytosis. Blood 102:4270-4276

Kluin-Nelemans HC, Ferenc V, van Doormaal JJ, van Iperen C, Peters WG, Akin C, Valent P (2009) Lenalidomide therapy in systemic mastocytosis. Leuk Res 33:e19-e22

Knapper S, Cullis J, Drummond MW, Evely R, Everington T, Hoyle C, McLintock L, Poynton C, Radia D (2011) Midostaurin a multitargeted oral kinase inhibitor in systemic mastocytosis: report of an open-label compassionate use program in the United Kingdom. Blood 118:5145

Koelink PJ, Overbeek SA, Braber S, de Kruijf P, Folkerts G, Smit MJ, Kraneveld AD (2012) Targeting chemokine receptors in chronic inflammatory diseases: an extensive review. Pharmacol Ther 133: $1-18$

Kohno M, Yamasaki S, Tybolewicz VLJ, Saito T (2005) Rapid and large amount of autocrine IL-3 production is responsible for mast cell survival by IgE in the absence of antigen. Blood 105:2059-2065

Kontou-Fili K, Filis CI, Voulgari C, Panayiotidis PG (2010) Omalizumab monotherapy for bee sting and unprovoked "anaphylaxis" in a patient with systemic mastocytosis and undetectable specific IgE. Ann Allergy Asthma Immunol 104:537-539

Krauth MT, Majlesi Y, Sonneck K, Samorapoompichit P, Ghannadan M, Hauswirth AW, Baghestanian M, Schernthaner GH, Worda C, Muller MR, Sperr WR, Valent P (2006) Effects of various statins on cytokine-dependent growth and IgE-dependent release of histamine in human mast cells. Allergy 61:281-288

Krauth MT, Böhm A, Agis H, Sonneck K, Samorapoompichit P, Florian S, Sotlar K, Valent P (2007) Effects of the CD33-targeted drug gemtuzumab ozogamicin (Mylotarg) on growth and mediator secretion in human mast cells and blood basophils. Exp Hematol 35:108116

Krug U, Lübbert M, Büchner T (2010) Maintenance therapy in acute myeloid leukemia revisited: will new agents rekindle an old interest? Curr Opin Hematol 17:85-90

Kurosawa M, Amano H, Kanbe N, Igarashi Y, Nagata H, Yamashita T, Kurimoto F, Miyachi Y (1999) Response to cyclosporin and lowdose methylprednisolone in aggressive systemic mastocytosis. J Allergy Clin Immunol 103:S412-S420

Kurzen H. (2009) Neramexane for the treatment of mast cellmediated diseases. Patent application WO2010/069595

Kvasnicka HM, Thiele J, Bueso-Ramos CE, Kamalanabhaiah S, Cortes JE, Kantajian H, Verstovsek S (2014) Changes in activated bone marrow macrophages and mast cells in patients with myelofibrosis following ruxolitinib therapy. ASH Meeting abstract 3184 
Laengle UW, Markstein R, Pralet D, Seewald W, Roman D (2006) Effect of GLC756, a novel mixed dopamine D1 receptor antagonist an dopamine $\mathrm{D} 2$ receptor agonist, on TNF-alpha release in vitro from activated rat mast cells. Exp Eye Res 83:1335-1339

Laroche M, Livideanu C, Paul C, Cantagrel A (2011) Interferon alpha and pamidronate in osteoporosis with fracture secondary to mastocytosis. Am J Med 124:776-778

Lasho T, Tefferi A, Pardanani A (2010) Inhibition of JAK-STAT signaling by TG101348: a novel mechanism for inhibition of KITD816Vdependent growth in mast cell leukemia cells. Leukemia 24:13781380

Lasho T, Finke C, Zblewski D et al. (2016) Concurrent activating KIT mutations in systemic mastocytosis. Br J Haematol 173:153-156

Lau HY, Kam MF (2005) Inhibition of mast cell histamine release by specific phosphodiesterase inhibitors. Inflamm Res 54(Supplement 1):05-06

Lechowski S, Feilhauer K, Staib L, Coëffier M, Bischoff SC, Lorentz A (2013) Combined arginine and glutamine decrease release of de novo synthesized leukotrienes and expression of proinflammatory cytokines in activated human intestinal mast cells. Eur J Nutr 52: 505-512

Lee YS, Kim MS, Lee DH, Kwon TH, Song HH, Oh SR, do Yoon Y (2015) Luteolin 8-C- $\beta$-fucopyranoside downregulates IL-6 expression by inhibiting MAPKs and the NF- $\mathrm{KB}$ signaling pathway in human monocytic cells. Pharmacol Rep 67:581-587

Lieberoth S, Thomsen SF (2015) Cutaneous and gastrointestinal symptoms in two patients with systemic mastocytosis successfully treated with omalizumab. Case Rep Med 2015:903541

Lim KH, Pardanani A, Butterfield JH, Li CY, Tefferi A (2009) Cytoreductive therapy in 108 adults with systemic mastocytosis: outcome analysis and response prediction during treatment with interferon-alpha, hydroxyurea, imatinib mesylate or 2-chlorodeoxyadenosine. Am J Hematol 84: 790-794

Lin TY, Bear M, Du Z, Foley KP, Ying W, Barsoum J, London C (2008) The novel HSP90 inhibitor STA-9090 exhibits activity against KITdependent and -independent malignant mast cell tumors. Exp Hematol 36:1266-1277

Lin TY, Fenger J, Murahari S, Bear MD, Kulp SK, Wang D, Chen CS, Kisseberth WC, London CA (2010) AR-42, a novel HDAC inhibitor, exhibits biologic activity against malignant mast cell lines via down-regulation of constitutively activated KIT. Blood 115:42174225

Lock AD, McNamara CJ, Rustin MH (2015) Sustained improvement in urticaria pigmentosa and pruritus in a case of indolent systemic mastocytosis treated with cladribine. Clin Exp Dermatol 40:142145

Lundequist A, Pejler G (2011) Biological implications of preformed mast cell mediators. Cell Mol Life Sci 68:965-975

Ma Z, Tovar JP, Kwong KY, Paek D (2010) Pimecrolimus induces apoptosis of mast cells in a murine model of cutaneous mastocytosis. Int Arch Allergy Immunol 153:413-418

Mallet AI, Norris P, Rendell NB, Wong E, Greaves MW (1989) The effect of disodium cromoglycate and ketotifen on the excretion of histamine and $\mathrm{N}$ tau-methylimidazole acetic acid in urine of patients with mastocytosis. Br J Clin Pharmacol 27:88-91

Marech I, Patruno R, Zizzo N, Gadaleta C, Introna M, Zito AF, Gadaleta CD, Ranieri G (2014) Masitinib (AB1010), from canine tumor model to human clinical development: where we are? Crit Rev Oncol Hematol 91:98-111

Marquardt DL, Gruber HE, Walker LL (1987) Ribavirin inhibits mast cell mediator release. J Pharmacol Exp Ther 240:145-149

Marton I, Pósfai É, Borbényi Z, Bödör C, Papp G, Demeter J, Korom I, Varga E, Bata-Csörgö Z (2015) Therapeutic challenge during the long-term follow-up of a patient with indolent systemic mastocytosis with extensive cutaneous involvement. Eur Rev Med Pharmacol Sci 19:1607-1609

Matsubara S, Li G, Takeda K, Loader JE, Pine P, Masuda ES, Miyahara N, Miyahara S, Lucas JJ, Dakhama A, Gelfand EW (2006) Inhibition of spleen tyrosine kinase prevents mast cell activation and airway hyperresponsiveness. Am J Respir Crit Care Med 173: 56-63

Mattace Raso G, Russo R, Calignano A, Meli R (2014) Palmitoylethanolamide in CNS health and disease. Pharmacol Res $86: 32-41$

Maurer M, Magerl M, Metz M, Weller K, Siebenhaar F (2013) Miltefosine: a novel treatment option for mast cell-mediated diseases. J Dermatolog Treat 24:244-249

McNeil BD, Pundir P, Meeker S, Han L, Undem BJ, Kulka M, Dong X (2015) Identification of a mast-cell-specific receptor crucial for pseudo-allergic drug reactions. Nature 519:237-241

Meeran SM, Ahmed A, Tollefsbol TO (2010) Epigenetic targets of bioactive dietary components for cancer prevention and therapy. Clin Epigenetics 1:101-116

Min YD, Choi CH, Bark H, Son HY, Park HH, Lee S, Park JW, Park EK, Shin HI, Kim SH (2007) Quercetin inhibits expression of inflammatory cytokines through attenuation of NF-kappaB and p38 MAPK in HMC-1 human mast cell line. Inflamm Res 56:210-215

Molderings GJ (2015) The genetic basis of mast cell activation diseaselooking through a glass darkly. Crit Rev Oncol Hematol 93:75-89

Molderings GJ (2016) Transgenerational transmission of systemic mast cell activation disease-genetic and epigenetic features. Transl Res.

Molderings GJ, Kolck UW, Scheurlen C, Brüss M, Homann J, Von Kügelgen I (2007) Multiple novel alterations in KIT tyrosine kinase in patients with gastrointestinally pronounced systemic mast cell activation disorder. Scand J Gastroenterol 42:1045-1053

Molderings GJ, Meis K, Kolck UW, Homann J, Frieling T (2010) Comparative analysis of mutation of tyrosine kinase KIT in mast cells from patients with systemic mast cell activation syndrome and healthy subjects. Immunogenetics 62:721-727

Molderings GJ, Brettner S, Homann J, Afrin LB (2011a) Mast cell activation disease: a concise practical guide for diagnostic workup and therapeutic options. J Hematol Oncol 4:10

Molderings GJ, Raithel M, Kratz F, Azemar M, Haenisch B, Harzer S, Homann J (2011b) Omalizumab treatment of systemic mast cell activation disease: experiences from four cases. Intern Med 50:1-5

Molderings GJ, Haenisch B, Bogdanow M, Fimmers R, Nöthen MM (2013a) Familial occurrence of systemic mast cell activation disease. PLoS One 8:e76241

Molderings GJ, Haenisch B, Homann J, Wilhelm T, Huber M (2013b) Neue Angriffspunkte der 1-4-Benzodiazepine in der mastzelspezifischen immunsuppressiven Therapie der sytemischen Mastzellüberaktivitätserkrankung. Gastroenterologe 8:170 abstract

Molderings GJ, Homann J, Brettner S, Raithel M, Frieling T (2014) Mast cell activation disease: a concise practical guide for diagnostic workup and therapeutic options. Dtsch Med Wochenschr 139:1523-1534

Moon PD, Lee BH, Jeong HJ, An HJ, Park SJ, Kim HR, Ko SG, Um JY, Hong SH, Kim HM (2007) Use of scopoletin to inhibit the production of inflammatory cytokines through inhibition of the IkB/NF-kB signal cascade in the human mast cell line HMC-1. Eur J Pharmacol 555:218-225

Mousli M, Hugli TE, Landry Y, Bronner C (1994) Peptidergic pathway in human skin and rat peritoneal mast cell activation. Immunopharmacology 27:1-11

Moussy A, Kinet JP (2014) Treatment of mastocytosis with masitinib. US Patent Application

Mühlenberg T, Zhang Y, Wagner AJ, Grabellus F, Bradner J, Taeger G, Lang H, Taguchi T, Schuler M, Fletcher JA, Bauer S (2009) Inhibitors of deacetylases suppress oncogenic KIT signaling, acetylate HSP90, and induce apoptosis in gastrointestinal stromal tumors. Cancer Res 69:6941-6950 
Nader MA (2011) Inhibition of anaphylaxis like reaction and mast cell activation by sitagliptin. Int Immunopharmacol 11:1052-1056

Nakamura R, Chakrabarti S, Akin C, Robyn J, Bahceci E, Greene A, Childs R, Dunbar CE, Metcalfe DD, Barrett AJ (2006) A pilot study of nonmyeloablative allogeneic hematopoietic stem cell transplant for advanced systemic mastocytosis. Bone Marrow Transplant 37: 353-358

Nolte H, Stahl Skov P (1988) Inhibition of basophil histamine release by methotrexate. Agents Actions 23:173-176

Nurmatov UB, Rhatigan E, Simons FE, Sheikh A (2015) H1antihistamines for primary mast cell activation syndromes: a systematic review. Allergy 70:1052-1061

Oppong E, Flink N, Cato AC (2013) Molecular mechanisms of glucocorticoid action in mast cells. Mol Cell Endocrinol 380:119-126

Otani IM, Bhagat M, Newbury RO, Dohil R, Broide DH, Aceves SS (2012) The effect of anti-IL-5 therapy on esophageal mastocytosis in pediatric eosinophilic esophagitis. J Allergy Clin Immunol 129: AB202

Paez P, Ryan J, Taruselli M, Ndaw V (2015) Fluvastatin elicits apoptosis in primary and transformed mast cells (INC6P.305). J Immunol 194(Suppl. 1):197.7

Pagano L, Valentini CG, Caira M, Rondoni M, Van Lint MT, Candoni A, Allione B, Cattaneo C, Marbello L, Caramatti C, Pogliani EM, Iannitto E, Giona F, Ferrara F, Invernizzi R, Fanci R, Lunghi M, Fianchi L, Sanpaolo G, Stefani PM, Pulsoni A, Martinelli G, Leone G, Musto P (2008) Advanced mast cell disease: an Italian Hematological Multicenter experience. Int J Hematol 88:483-488

Paivandy A, Calounova G, Zarnegar B, Ohrvik H, Melo FR, Pejler G (2014) Mefloquine, an anti-malaria agent, causes reactive oxygen species-dependent cell death in mast cells via a secretory granulemediated pathway. Pharmacol Res Perspect 2:e00066

Pan J, Quintas-Cardama A, Kantarjian HM, Akin C, Manshouri T, Lamb P, Cortes JE, Tefferi A, Giles FJ, Verstovsek S (2007) EXEL-0862, a novel tyrosine kinase inhibitor, induces apoptosis in vitro and ex vivo in human mast cells expressing the KIT D816V mutation. Blood 109:315-322

Papaetis GS, Syrigos KN (2009) Sunitinib: a multitargeted receptor tyrosine kinase inhibitor in the era of molecular cancer therapies. BioDrugs 23:377-389

Papayannidis C, Soverini S, Benedittis CD, Abbenante MC, Sartor C, Iacobucci I, Baldazzi C, Ottaviani E, Ferrari A, Guadagnuolo V, Conficoni A, Paolini S, Parisi S, Frabetti F, Piccari S, Grilli S, Lani E, Martinelli G (2014) PKC412 (midostaurin) is safe and highly effective in systemic mastocytosis patients: follow up of a singlecenter Italian compassionate use. Cancer Res 74:746

Pardanani A (2013) Systemic mastocytosis in adults: 2013 update on diagnosis, risk stratification, and management. Am J Hematol 88: $612-624$

Pardanani A, Elliott M, Reeder T, Li CY, Baxter EJ, Cross NC, Tefferi A (2003) Imatinib for systemic mast-cell disease. Lancet 362:535-536

Pardanani A, Hoffbrand AV, Butterfield JH, Tefferi A (2004) Treatment of systemic mast cell disease with 2-chlorodeoxyadenosine. Leuk Res 28:127-131

Parikh SA, Kantarjian HM, Richie MA, Cortes JE, Verstovsek S (2010) Experience with everolimus (RAD001), an oral mammalian target of rapamycin inhibitor, in patients with systemic mastocytosis. Leuk Lymphoma 51:269-274

Park TH (2013) The effects of botulinum toxin A on mast cell activity: preliminary results. Burns 39:816-817

Paul C, Sans B, Suarez F, Casassus P, Barete S, Lanternier F, GrandpeixGuyodo C, Dubreuil P, Palmérini F, Mansfield CD, Gineste P, Moussy A, Hermine O, Lortholary O (2010) Masitinib for the treatment of systemic and cutaneous mastocytosis with handicap: a phase 2a study. Am J Hematol 85:921-925

Peter B, Hadzijusufovic E, Blatt K, Gleixner KV, Pickl WF, Thaiwong T, Yuzbasiyan-Gurkan V, Willmann M, Valent P (2010) KIT polymorphisms and mutations determine responses of neoplastic mast cells to bafetinib (INNO-406). Exp Hematol 38:782-791

Peter B, Gleixner KV, Cerny-Reiterer S, Herrmann H, Winter V, Hadzijusufovic E, Ferenc V, Schuch K, Mirkina I, Horny HP, Pickl WF, Mullauer L, Willmann M, Valent P (2011) Polo-like kinase-1 as novel target in neoplastic mast cells: demonstration of growth-inhibitory effects of siRNA and the Polo-like kinase-1 targeting drug BI 2536. Haematologica 96(5):672-680

Picard M, Giavina-Bianchi P, Mezzano V, Castells M (2013) Expanding spectrum of mast cell activation disorders: monoclonal and idiopathic mast cell activation syndromes. Clin Ther 35:548-562

Purtill D, Cooney J, Sinniah R, Carnley B, Cull G, Augustson B, Cannell P (2008) Dasatinib therapy for systemic mastocytosis: four cases. Eur J Haematol 80:456-458

Quintás-Cardama A, Jain N, Verstovsek S (2011) Advances and controversies in the diagnosis, pathogenesis, and treatment of systemic mastocytosis. Cancer 117:5439-5449

Quintás-Cardama A, Sever M, Cortes J, Kantarjian H, Verstovsek S (2013) Bone marrow mast cell burden and serum tryptase level as markers of response in patients with systemic mastocytosis. Leuk Lymphoma 54:1959-1964

Radojković M, Ristić S, Colović N, Terzić T, Colović M (2011) Response to cladribine in patient with systemic mastocytosis. Vojnosanit Pregl 68:444-446

Randall N, Courville EL, Baughn L, Afrin L, Ustun C (2015) Bosutinib, a lyn/btk inhibiting tyrosine kinase inhibitor, is ineffective in advanced systemic mastocytosis. Am J Hematol 90:E74

Ritter M, El-Nour H, Hedblad MA, Butterfield JH, Beck O, Stephanson N, Holst M, Giscombe R, Azmitia EC, Nordlind K (2012) Serotonin and its 5-HT1 receptor in human mastocytosis. Immunopharmacol Immunotoxicol 34:679-685

Rodrigo L, Perez-Martinez I, Lucendo AJ (2013) Urticaria pigmentosa in a female patient wth celiac disease: response to a gluten-free diet. Allergol Immunopathol (Madr) 41:128-130

Rodrigues JM, Pazin Filho A, Rodrigues AJ, Vicente WV, Evora PR (2007) Methylene blue for clinical anaphylaxis treatment: a case report. Sao Paulo Med J 125:60-62

Rodriguez T, Pfeffer M, Levy BD, Castells M (2011) Lipid mediators in cutaneous and systemic mastocytosis and the impact of 5-LO inhibition. J Allergy Clin Immunol 127(Suppl):AB132

Rosen H, Goetzl EJ (2005) Sphingosine 1-phosphate and its receptors: an autocrine and paracrine network. Nat Rev Immunol 5:560-570

Ruano I, Gargini R, Izquierdo M (2010) Combination of KIT gene silencing and tocopherol succinate may offer improved therapeutic approaches for human mastocytosis. Br J Haematol 148:59-68

Sagi L, Solomon M, Baum S, Lyakhovitsky A, Trau H, Barzilai A (2011) Evidence for methotrexate as a useful treatment for steroiddependent chronic urticaria. Acta Derm Venereol 91:303-306

Sandler C, Nurmi K, Lindstedt KA, Sorsa T, Golub LM, Kovanen PT, Eklund KK (2005) Chemically modified tetracyclines induce apoptosis in cultured mast cells. Int Immunohistopharmacol 5:16111621

Schittenhelm MM, Akmut F, Illing B, Frey J, Schuster K, Ramachandran A, Kanz L, Kampa-Schittenhelm KM (2014) Gain-of-function KIT mutations sensitize the mutant isoform to the type I tyrosine kinase inhibitor crenolanib: a rationale for the therapeutic use in systemic mastocytosis (SM) and core binding factor leukemias (CBFL). ASH-Meeting abstract 2230

Seifert R (2015) How do basic secretagogues activate mast cells? Naunyn Schmiedeberg's Arch Pharmacol 388:279-281

Shimoda T, Liang Z, Suzuki H, Kawana S (2010) Inhibitory effects of antipsychotic and anxiolytic agents on stress-induced degranulation of mouse dermal mast cells. Clin Exp Dermatol 35:531-536

Sido B, Dumoulin FL, Homann J, Hertfelder HJ, Bollmann M, Molderings GJ (2014) Surgical interventions in patients with mast 
cell activation disease. Aspects relevant for surgery using the example of a cholecystectomy. Chirurg 85:327-333

Siebenhaar F, Förtsch A, Krause K, Weller K, Metz M, Magerl M, Martus P, Church MK, Maurer M (2013) Rupatadine improves quality of life in mastocytosis: a randomized, double-blind, placebo-controlled trial. Allergy 68:949-952

Simhadri VR, Andersen JF, Calvo E, Choi SC, Coligan JE, Borrego F (2012) Human CD300a binds to phosphatidylethanolamine and phosphatidylserine, and modulates the phagocytosis of dead cells. Blood 119:2799-2809

Simon J, Lortholary O, Caillat-Vigneron N, Raphael M, Martin A, Briere J, Barete S, Hermine O, Casussus P (2004) Interest of interferon alpha in systemic mastocytosis. The french experience and review of the literature. Pathol Biol 52:294-299

Soter NA, Austen KF, Wasserman SI, Soter NA, Austen KF, Wasserman SI (1979) Oral disodium cromoglycate in the treatment of systemic mastocytosis. N Engl J Med 301:465-469

Spirkoski J, Melo FR, Grujic M, Calounova G, Lundequist A, Wernersson S, Pejler G (2012) Mast cell apoptosis induced by siramesine, a sigma-2 receptor agonist. Biochem Pharmacol 84: $1671-1680$

Spyridonidis A, Thomas AK, Bertz H, Zeiser R, Schmitt-Graff A, Lindemann A, Waller CF, Finke J (2004) Evidence for a graftversus-mast-cell effect after allogeneic bone marrow transplantation. Bone Marrow Transplant 34:515-519

Strati P, Kantarjian H, Ravandi F, Nazha A, Borthakur G, Daver N, Kadia T, Estrov Z, Garcia-Manero G, Konopleva M, Rajkhowa T, Durand M, Andreeff M, Levis M, Cortes J (2015) Phase I/II trial of the combination of midostaurin (PKC412) and 5-azacytidine for patients with acute myeloid leukemia and myelodysplastic syndrome. Am J Hematol 90:276-281

Suzuki-Nishimura T, Sano T, Uchida MK (1989) Effects of benzodiazepines on serotonin release from rat mast cells. Eur J Pharmacol 167: $75-85$

Tachibana M, Wada K, Katayama K, Kamisaki Y, Maeyama K, Kadowaki T, Blumberg RS, Nakajima A (2008) Activation of peroxisome proliferator-activated receptor gamma suppresses mast cell maturation involved in allergic diseases. Allergy 63:1136-1147

Tanaka A, Konno M, Muto S, Kambe N, Morii E, Nakahata T, Itai A, Matsuda H (2005) A novel NF-kappa B inhibitor, IMD-0354, suppresses neoplastic proliferation of human mast cells with constitutively activated c-Kit receptors. Blood 105:2324-2331

Tang C, Lan C, Wang C, Liu R (2005) Amelioration of the development of multiple organ dysfunction syndrome by somatostatin via suppression of intestinal mucosal mast cells. Shock 23:470-475

Tanimoto A, Ogawa Y, Oki C, Kimoto Y, Nozawa K, Amano W, Noji S, Shiozaki M, Matsuo A, Shinozaki Y, Matsushita M (2015) Pharmacological properties of JTE-052: a novel potent JAK inhibitor that suppresses various inflammatory responses in vitro and in vivo. Inflamm Res 64:41-51

Tefferi A, Li CY, Butterfield JH, Hoagland HC (2001) Treatment of systemic mast-cell disease with cladribine. N Engl J Med 344: 307-309

Tolar J, Tope WD, Neglia JP (2004) Leukotriene-receptor inhibition for the treatment of systemic mastocytosis. N Engl J Med 350:735-736

Topar G, Staudacher C, Geisen F, Gabl C, Fend F, Herold M, Greil R, Fritsch P, Sepp N (1998) Urticaria pigmentosa: a clinical, hematopathologic, and serologic study of 30 adults. Am J Clin Pathol 109:279-285

Trojan TD, Khan DA (2012) Calcineurin inhibitors in chronic urticaria. Curr Opin Allergy Clin Immunol 12:412-420

Turner PJ, Kemp AS, Rogers M, Mehr S (2012) Refractory symptoms successfully treated with leukotriene inhibition in a child with systemic mastocytosis. Pediatr Dermatol 29:222-223
Uchida K, Mitsui M, Kawakishi S (1989) Monooxygenation of Nacetylhistamine mediated by L-ascorbate. Biochim Biophys Acta 991:377-379

Ustun C, Reiter A, Scott BL, Nakamura R, Damaj G, Kreil S, Shanley R, Hogan WJ, Perales MA, Shore T, Baurmann H, Stuart R, Gruhn B, Doubek M, Hsu JW, Tholouli E, Gromke T, Godley LA, Pagano L, Gilman A, Wagner EM, Shwayder T, Bornhäuser M, Papadopoulos EB, Böhm A, Vercellotti G, Van Lint MT, Schmid C, Rabitsch W, Pullarkat V, Legrand F, Yakoub-Agha I, Saber W, Barrett J, Hermine O, Hagglund H, Sperr WR, Popat U, Alyea EP, Devine S, Deeg HJ, Weisdorf D, Akin C, Valent P (2014) Hematopoietic stem-cell transplantation for advanced systemic mastocytosis. J Clin Oncol 32: 3264-3274

Vaali K, Lappalainen J, Lin AH, Mäyränpää MI, Kovanen PT, Berstad A, Eklund KK (2012) Imatinib mesylate alleviates diarrhea in a mouse model of intestinal allergy. Neurogastroenterol Motil 24:e325-e335

Valent P, Horny HP, Escribano L, Longley BJ, Li CY, Schwartz LB, Marone G, Nuñez R, Akin C, Sotlar K, Sperr WR, Wolff K, Brunning RD, Parwaresch RM, Austen KF, Lennert K, Metcalfe DD, Vardiman JW, Bennett JM (2001) Diagnostic criteria and classification of mastocytosis: a consensus proposal. Leuk Res 25:603625

Valent P, Akin C, Escribano L, Födinger M, Hartmann K, Brockow K, Castells M, Sperr WR, Kluin-Nelemans HC, Hamdy NA, Lortholary O, Robyn J, van Doormaal J, Sotlar K, Hauswirth AW, Arock M, Hermine O, Hellmann A, Triggiani M, Niedoszytko M, Schwartz LB, Orfao A, Horny HP, Metcalfe DD (2007) Standards and standardization in mastocytosis: consensus statements on diagnostics, treatment recommendations and response criteria. Eur J Clin Investig 37:435-453

Valent P, Sperr WR, Akin C (2010) How I treat patients with advanced systemic mastocytosis. Blood 116:5812-5817

Valent P, Akin C, Arock M, Brockow K, Butterfield JH, Carter MC, Castells M, Escribano L, Hartmann K, Lieberman P, Nedoszytko B, Orfao A, Schwartz LB, Sotlar K, Sperr WR, Triggiani M, Valenta R, Horny HP, Metcalfe DD (2012) Definitions, criteria and global classification of mast cell disorders with special reference to mast cell activation syndromes: a consensus proposal. Int Arch Allergy Immunol 157:215-225

van Doormaal JJ, Idema IG, de Monchy JG, Breukelman H, Keyzer JJ, Doorenbos H (1986) Effects of isoprenaline and terbutaline on urinary excretion of histamine and its two main metabolites in systemic mastocytosis. Agents Actions 18:269-272

van Doormaal JJ, Arends S, Brunekreeft KL, et al. (2013) Prevalence of indolent systemic mastocytosis in a Dutch region. J Allergy Clin Immunol 131:1429-1431

Vega-Ruiz A, Cortes JE, Sever M, Manshouri T, Quintás-Cardama A, Luthra R, Kantarjian HM, Verstovsek S (2009) Phase II study of imatinibmesylate as therapy for patients with systemic mastocytosis. Leuk Res 33:1481-1484

Verstovsek S, Tefferi A, Cortes J, O'Brien S, Garcia-Manero G, Pardanani A, Akin C, Faderl S, Manshouri T, Thomas D, Kantarjian H (2008) Phase II study of dasatinib in Philadelphia chromosome-negative acute and chronic myeloid diseases, including systemic mastocytosis. Clin Cancer Res 14:3906-3915

Vrugt B, Wilson S, Bron A, Shute J, Holgate ST, Djukanovic R, Aalbers $\mathrm{R}$ (2000) Low-dose methotrexate treatment in severe glucocorticoid-dependent asthma: effect on mucosal inflammation and in vitro sensitivity to glucocorticoids of mitogen-induced T-cell proliferation. Eur Respir J 15:478-485

Welch EA, Alper JC, Bogaars H, Farrell DS (1983) Treatment of bullous mastocytosis with disodium cromoglycate. J Am Acad Dermatol 9: 349-353

Weller K, Artuc M, Jennings G, Friedrichson T, Guhl S, Dos Santos RV, Sünder C, Zuberbier T, Maurer M (2009) Miltefosine inhibits 
human mast cell activation and mediator release both in vitro and in vivo. J Invest Dermatol 129:496-498

Weng Z, Zhang B, Asadi S, Sismanopoulos N, Butcher A, Fu X, Katsarou-Katsari A, Antoniou C, Theoharides TC (2012) Quercetin is more effective than cromolyn in blocking human mast cell cytokine release and inhibits contact dermatitis and photosensitivity in humans. PLoS One 7:e33805

Weng Z, Patel AB, Panagiotidou S, Theoharides TC (2015) The novel flavone tetramethoxyluteolin is a potent inhibitor of human mast cells. J Allergy Clin Immunol 135:1044-1052

Worobec AS, Kirshenbaum AS, Schwartz LB, Metcalfe DD (1996) Treatment of three patients with systemic mastocytosis with interferon alpha-2b. Leuk Lymphoma 22:501-508

Yacoub A, Prochaska L (2016) Ruxolitinib improves symptoms and quality of life in a patient with systemic mastocytosis. Biomark Res 4:2

Yamaguchi S, Okada Y, Matsunaga Y, Nambu F (2016) Effect of ONO4053 on FceRI stimulated mast cell activation. J Allergy Clin Immunol 137:AB77
Yamaki K, Yoshino S (2012) Tyrosine kinase inhibitor sunitinib relieves systemic and oral antigen-induced anaphylaxes in mice. Allergy 67: $114-122$

Yang Y, Lu JY, Wu X, Summer S, Whoriskey J, Saris C, Reagan JD (2010) G-protein-coupled receptor 35 is a target of the asthma drugs cromolyn disodium and nedocromil sodium. Pharmacology 86:1-5

Yoshida C, Takeuchi M, Tsuchiyama J, Sadahira Y (2009) Successful treatment of KIT D816V-positive, imatinib-resistant systemic mastocytosis with interferon-alpha. Intern Med 48:1973-1978

Zachariae H, Herlin T, Larsen PO (1981) Oral disodium cromoglycate in mastocytosis. Acta Derm Venereol 61:272-273

Zen M, Canova M, Campana C, Bettio S, Nalotto L, Rampudda M, Ramonda R, Iaccarino L, Doria A (2011) The kaleidoscope of glucorticoid effects on immune system. Autoimmun Rev 10:305310

Zhang T, Finn DF, Barlow JW, Walsh JJ (2016) Mast cell stabilisers. Eur J Pharmacol 778:158-168 